\title{
Clinical, economic, and humanistic burden of asthma in Canada: a systematic review
}

Afisi S Ismaila ${ }^{1,2^{*}}$, Amyn P Sayani ${ }^{1}$, Mihaela Marin ${ }^{3}$ and Zhen Su ${ }^{4}$

\begin{abstract}
Background: Asthma, one of the most common chronic respiratory diseases, affects about 3 million Canadians. The objective of this study is to provide a comprehensive evaluation of the published literature that reports on the clinical, economic, and humanistic burden of asthma in Canada.

Methods: A search of the PubMed, EMBASE, and EMCare databases was conducted to identify original research published between 2000 and 2011 on the burden of asthma in Canada. Controlled vocabulary with "asthma" as the main search concept was used. Searches were limited to articles written in English, involving human subjects and restricted to Canada. Articles were selected for inclusion based on predefined criteria like appropriate study design, disease state, and outcome measures. Key data elements, including year and type of research, number of study subjects, characteristics of study population, outcomes evaluated, results, and overall conclusions of the study, were abstracted and tabulated.
\end{abstract}

Results: Thirty-three of the 570 articles identified by the clinical and economic burden literature searches and 14 of the 309 articles identified by the humanistic burden literature searches met the requirements for inclusion in this review. The included studies highlighted the significant clinical burden of asthma and show high rates of healthcare resource utilization among asthma patients (hospitalizations, ED, physician visits, and prescription medication use). The economic burden is also high, with direct costs ranging from an average annual cost of $\$ 366$ to $\$ 647$ per patient and a total annual population-level cost ranging from \$46 million in British Columbia to $\$ 141$ million in Ontario. Indirect costs due to time loss from work, productivity loss, and functional impairment increase the overall burden. Although there is limited research on the humanistic burden of asthma, studies show a high (31\%-50\%) prevalence of psychological distress and diminished QoL among asthma patients relative to subjects without asthma.

Conclusions: As new therapies for asthma become available, economic evaluations and assessment of clinical and humanistic burden will become increasingly important. This report provides a comprehensive resource for health technology assessment that will assist decision making on asthma treatment selection and management guidelines in Canada.

Keywords: Asthma, Literature review, Burden of illness, Costs, Quality of life

\footnotetext{
* Correspondence: afisi.s.ismaila@gsk.com

${ }^{1}$ Medical Affairs, GlaxoSmithKline Canada, Mississauga, ON, Canada

${ }^{2}$ Department of Clinical Epidemiology and Biostatistics, McMaster University,

Hamilton, Ontario, Canada

Full list of author information is available at the end of the article
} 


\section{Background}

Asthma, an inflammatory disorder of the airways [1], accounts for roughly $80 \%$ of cases of chronic respiratory disease in Canada [2]. It affects more than 3 million Canadians and roughly 235 million people worldwide $[3,4]$. According to Statistics Canada, $8.5 \%$ of the population aged 12 and older has been diagnosed with asthma [5]. Its prevalence in this country has been increasing over the last 20 years [3]. Worldwide, asthma prevalence rates have been rising on average by $50 \%$ every decade [3]. Notably, asthma is the leading cause of hospital admissions in the overall Canadian population [3,6], the leading cause of absenteeism from school, and the third leading cause of work loss [3]. Each year, there are 146,000 emergency room visits due to asthma attacks in Canada [3]. Asthma is also a major cause of hospitalization [7] among the estimated 13\% of Canadian children who suffer from the disease [8].

High prevalence in conjunction with significant asthmarelated morbidity leads to a heavy clinico-economic and humanistic burden of asthma in Canada $[9,10]$. Healthcare utilization and costs are even higher when management and control of the disease are suboptimal [11]. The direct and indirect costs associated with asthma are expected to rank among the highest for chronic diseases due to the significant healthcare utilization associated with the disease [9] and asthma's detrimental impact on physical, emotional, social, and professional lives of sufferers [12].

This systematic review is the first to consolidate and summarize the literature (from 2000-2011) encompassing not only the clinical and economic, but also the humanistic burden of asthma in Canada. It, thus, provides a holistic overview of the weight this disease poses to the healthcare system, patients and society. Specifically, this systematic literature review unveils the direct and indirect costs of asthma per patient, the key drivers of healthcare resource utilization, and the humanistic impact of asthma on patients' quality of life (QoL), which cannot be inferred from clinical measures [13]. This information, consolidated in a single review, can be of value to payers, policy makers and healthcare providers in making decisions pertaining to the management and treatment of asthma.

\section{Methods}

We conducted a search of the PubMed, EMBASE, and EMCare databases to identify original research (crosssectional, observational, or longitudinal studies on the burden-of-illness and cost-of-illness) published from 2000 to 2011 on the burden of asthma in Canada. Review articles, letters, editorials, commentaries, studies reporting summaries of meeting proceedings or conferences, abstracts or posters presented at scientific meetings, and studies assessing the efficacy or effectiveness of specific interventions were not included. The time frame was selected to reflect more recent developments in the treatment and management of asthma in Canada.

Each search was conducted using controlled vocabulary and key words, with "asthma" as the main search concept. Search terms included "Canada," "cost of illness," "hospitalization," "utilization," "burden of illness," "quality of life," "sickness impact profile," and "healthcare cost." Appendix shows the detailed search strategies for each topic area. Searches were limited to articles published in English and studies involving humans. Studies were restricted to Canada.

Titles and abstracts of articles identified were carefully screened in the initial review for relevance to the topic. At the second review, articles were selected for inclusion based on predefined acceptance criteria, which included relevant patient population (ie, adults/children diagnosed with asthma) and appropriate study design and outcome measures (patient- and population-level). Two independent reviewers determined whether studies met the inclusion criteria, and discrepancies between reviewer decisions were resolved in consensus.

Reasons for study exclusions were recorded. For articles that met predefined inclusion/exclusion criteria, the quality of the studies was assessed using methodological checklists provided in the NICE Guidelines Manual [14] and the STROBE (STrengthening the Reporting of OBservational studies in Epidemiology) guidelines [15,16]. Key data elements were abstracted and tabulated in summary tables: year and type of study, number of study subjects, asthma definition, characteristics of study population, outcomes evaluated, results, and overall conclusions of the study.

Reported costs were inflated to 2011 Canadian dollars (CAD) using the Consumer Price Index from Statistics Canada [17].

\section{Results}

Figure 1 depicts the step-by-step study selection process. The MEDLINE, EMBASE, and EMCare database searches yielded 320 citations, 230 citations, and 20 citations, respectively.

In the first-level selection process (based on the information presented in the article abstracts) for the clinicoeconomic burden, 503 of the 570 citations were rejected: 174 reported inappropriate outcomes (i.e., outcomes that were not aligned with the outcomes of interest), 150 due to inappropriate disease state (eg, the studies focused on other chronic respiratory diseases or included only a small number of the subjects with asthma), and 91 due to inappropriate study design. Other reasons for rejection during the first-level selection process are shown in Figure 1. Of the 67 full-text articles retrieved for potential inclusion, 34 were excluded during the second-level 


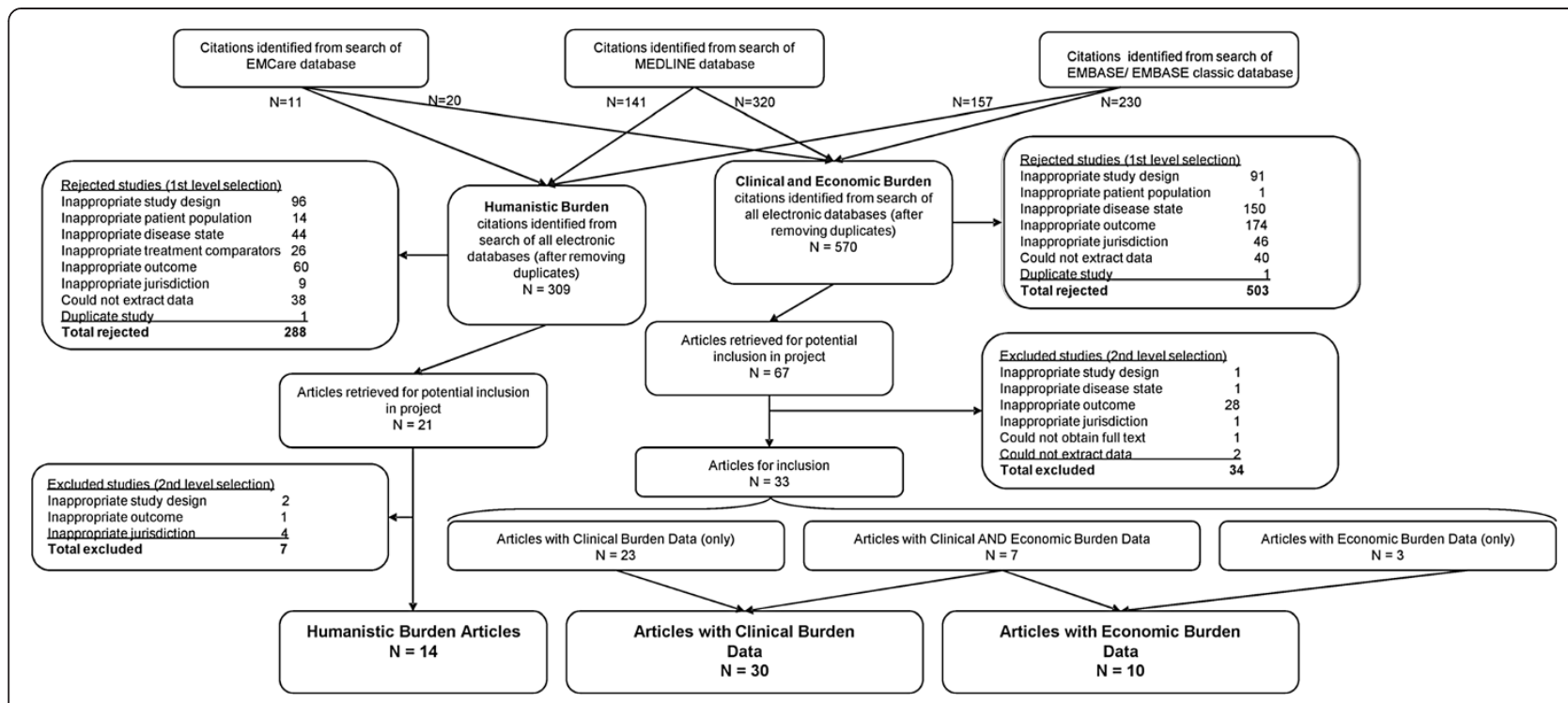

Figure 1 Process for studies to be included in the review.

selection process (28 due to inappropriate outcomes). Thus, 33 articles fulfilled all criteria and were included in the clinico-economic burden review (Figure 1).

After duplicates were removed, 309 studies were identified by the humanistic burden literature searches from the 3 databases. Of these, 288 studies were excluded during the first-level selection for inappropriate disease state $(n=44)$, inappropriate outcome measure $(n=60)$, inappropriate study design $(\mathrm{n}=96)$, jurisdiction $(\mathrm{n}=9)$, inappropriate patient population $(\mathrm{n}=14)$, treatment comparator $(n=26)$, because data could not be extracted in the required format $(n=38)$, or because they were duplicate studies $(n=1)$. Twenty-one studies were selected for potential inclusion in the review. During the secondlevel selection, full-text articles were reviewed and a further 7 were excluded for inappropriate outcome measure $(\mathrm{n}=1)$, study design $(\mathrm{n}=2)$ or jurisdiction $(\mathrm{n}=4)$. Fourteen articles fulfilled all criteria and were included in the humanistic burden review (Figure 1).

Table 1 depicts the quality assessment of the articles on clinical, economic, and humanistic burden using STROBE tools, and Table 2 summarizes quality assessment of the articles on clinical burden using the NICE $\mathrm{RCT}$ assessment tool.

\section{Clinical burden studies}

\section{Overview}

Of the 33 studies meeting all criteria for inclusion, 23 contained clinical burden data only, 7 had information on both clinical and economic burden of asthma, and 3 had data on the economic burden of asthma only.

Of the 30 studies on clinical burden, 1 was a casecontrol, 22 were cohort, and 7 were cross-sectional studies. Characteristics of studies reporting on clinical burden are shown in Table 3.

Most studies clearly reported the study design (97\%), setting (100\%), participants (87\%), and statistical methods employed (70\%). However, less than half reported on potential sources of bias and confounding factors or how missing data was handled. Furthermore, less than half of the studies reported on how loss to followup was addressed in both the methods and results sections, or how sensitivity analyses were conducted. Main results for outcomes data were appropriately reported in $97 \%$ of the clinical burden studies, and more than $90 \%$ met the STROBE criteria for appropriate quality discussion. Most $(77 \%)$ gave the source of study funding and the roles of the funders. (Tables 1 and 2).

Studies employed a variety of definitions for asthma, including ICD codes, physician visits and/or hospitalizations for asthma (based on billing codes), asthma medication prescriptions filled, and patient self-report. We report the definitions used, but these definitions were not reconciled in this review. When asthma was defined by the presence of ICD codes, it was considered to be narrowly defined, whereas a broad asthma definition included visits for an asthma-related diagnosis and asthma-related hospitalizations among the discharge diagnoses.

\section{Key findings on clinical burden Hospitalizations}

Table 4 provides an overview of hospitalization rates for adult and pediatric patients with asthma in Canada. Reported rates of hospitalization for asthma varied widely according to age, geographic region, gender, and asthma medication use. In a large cohort study spanning over 
Table 1 Summary of quality assessment (using STROBE assessment tools) of the articles included

\begin{tabular}{|c|c|c|c|c|c|}
\hline \multirow[t]{2}{*}{ Report section } & \multirow[t]{2}{*}{ Item } & \multirow{2}{*}{$\begin{array}{l}\text { Item } \\
\#\end{array}$} & \multicolumn{3}{|c|}{$\%$ articles with STROBE criteria not met } \\
\hline & & & Clinical burden & Economic burden & Humanistic burden \\
\hline \multirow[t]{2}{*}{ Title and abstract } & Title & $1 a$ & $20 \%$ & $40 \%$ & $10 \%$ \\
\hline & Abstract & $1 b$ & $13 \%$ & $30 \%$ & $0 \%$ \\
\hline \multirow[t]{2}{*}{ Introduction } & Background/rationale & 2 & $0 \%$ & $0 \%$ & $0 \%$ \\
\hline & Objective & 3 & $0 \%$ & $0 \%$ & $0 \%$ \\
\hline \multirow[t]{14}{*}{ Methods } & Study design & 4 & $3 \%$ & $10 \%$ & $0 \%$ \\
\hline & Setting & 5 & $0 \%$ & $0 \%$ & $0 \%$ \\
\hline & Participants & $6 a$ & $13 \%$ & $10 \%$ & $0 \%$ \\
\hline & & $6 b$ & $30 \%$ & $10 \%$ & $10 \%$ \\
\hline & Variables & 7 & $23 \%$ & $30 \%$ & $30 \%$ \\
\hline & Data sources/measurement & 8 & $10 \%$ & $10 \%$ & $0 \%$ \\
\hline & Bias & 9 & $53 \%$ & $40 \%$ & $40 \%$ \\
\hline & Study size & 10 & $20 \%$ & $30 \%$ & $30 \%$ \\
\hline & Quantitative variables & 11 & $13 \%$ & $20 \%$ & $20 \%$ \\
\hline & Statistical methods & $12 a$ & $30 \%$ & $30 \%$ & $10 \%$ \\
\hline & & $12 b$ & $47 \%$ & $60 \%$ & $20 \%$ \\
\hline & & $12 \mathrm{C}$ & $70 \%$ & $60 \%$ & $50 \%$ \\
\hline & & $12 \mathrm{~d}$ & $60 \%$ & $60 \%$ & $30 \%$ \\
\hline & & $12 \mathrm{e}$ & $77 \%$ & $50 \%$ & $80 \%$ \\
\hline \multirow[t]{11}{*}{ Results } & Participants & $13 a$ & $40 \%$ & $50 \%$ & $30 \%$ \\
\hline & & $13 b$ & $63 \%$ & $60 \%$ & $30 \%$ \\
\hline & & $13 c$ & $73 \%$ & $80 \%$ & $50 \%$ \\
\hline & Descriptive data & $14 a$ & $37 \%$ & $50 \%$ & $20 \%$ \\
\hline & & $14 b$ & $77 \%$ & $80 \%$ & $60 \%$ \\
\hline & & $14 c$ & $27 \%$ & $20 \%$ & $20 \%$ \\
\hline & Outcome data & 15 & $3 \%$ & $10 \%$ & $0 \%$ \\
\hline & Main results & $16 a$ & $27 \%$ & $30 \%$ & $0 \%$ \\
\hline & & $16 b$ & $63 \%$ & $70 \%$ & $20 \%$ \\
\hline & & $16 c$ & $40 \%$ & $70 \%$ & $30 \%$ \\
\hline & Other analyses & 17 & $37 \%$ & $20 \%$ & $60 \%$ \\
\hline \multirow[t]{4}{*}{ Discussion } & Key results & 18 & $0 \%$ & $0 \%$ & $0 \%$ \\
\hline & Limitations & 19 & $7 \%$ & $20 \%$ & $20 \%$ \\
\hline & Interpretation & 20 & $3 \%$ & $10 \%$ & $0 \%$ \\
\hline & Generalizability & 21 & $3 \%$ & $10 \%$ & $20 \%$ \\
\hline Other & Funding & 22 & $23 \%$ & $40 \%$ & $20 \%$ \\
\hline
\end{tabular}

Table 2 Summary of quality assessment (using NICE RCT assessment tool) of the articles included

\begin{tabular}{lll}
\hline $\begin{array}{l}\text { Type of } \\
\text { bias }\end{array}$ & \multicolumn{2}{l}{ Humanistic burden $(\mathbf{n}=\mathbf{4})$} \\
\cline { 2 - 3 } & Low risk & Unclear risk \\
\hline Selection & 2 & 2 \\
Performance & 3 & 1 \\
Attrition & 2 & 2 \\
Detection & 3 & 1 \\
\hline
\end{tabular}

20 years, Suissa et al. [41] obtained data from the Saskatchewan Health databases on asthma patients from that province aged 5-44 between 1975 and 1991 and found that the overall rate of asthma hospitalization was 42 per 1000 asthma patients per year in patients with at least 1 year of follow-up. The rate was higher (48 per 1000) in patients receiving at least 3 anti-asthma medication prescriptions in any 1 year. During the variable follow-up period (up to 4 years), regular use of inhaled corticosteroids (ICS) was associated with a $31 \%$ 
Table 3 Characteristics of clinical burden studies included in the review

\begin{tabular}{|c|c|c|c|c|}
\hline Reference/Study period & Data source & Study objective & Inclusion criteria & Asthma definition \\
\hline \multicolumn{5}{|l|}{ Retrospective cohort studies } \\
\hline \multirow{4}{*}{$\begin{array}{l}\text { Sadatsafavi et al. } \\
2010[10] \\
1996-2000\end{array}$} & \multirow{4}{*}{$\begin{array}{l}\text { Administrative } \\
\text { healthcare data }\end{array}$} & \multirow{4}{*}{$\begin{array}{l}\text { Determine direct medical costs of asthma- } \\
\text { related healthcare in British Columbia }\end{array}$} & 5 to 55 years & \multirow{4}{*}{$\begin{array}{l}\text { Narrow: ICD-9 493.x Broad: visits for an } \\
\text { asthma-related diagnosis; hospitalizations with } \\
\text { asthma among the discharge diagnoses }\end{array}$} \\
\hline & & & $\geq 4$ asthma prescriptions in 1 year & \\
\hline & & & $\geq 1$ asthma hospitalization & \\
\hline & & & $\geq 2$ physician visits for asthma & \\
\hline \multirow{3}{*}{$\begin{array}{l}\text { Blais et al. } 2011 \\
\text { [18] } 1998-2005\end{array}$} & \multirow[t]{3}{*}{ RAMQ database, } & \multirow{3}{*}{$\begin{array}{l}\text { Determine relationship between better } \\
\text { use of LTRA and asthma exacerbations in } \\
\text { children }\end{array}$} & 5-15 years & \multirow{3}{*}{$\begin{array}{l}\text { Moderate or severe asthma exacerbations - an } \\
\text { ED visit for asthma, a hospital admission for } \\
\text { asthma, or a dispensed short-course ( } 14 \text { days) } \\
\text { prescription of oral corticosteroids }\end{array}$} \\
\hline & & & Diagnosed asthma & \\
\hline & & & Initiating (mono)therapy with ICS or LTRA & \\
\hline $\begin{array}{l}\text { Rosychuk et al. } \\
2010 \text { [19] } \\
\text { Apr } 1999 \text { to } \\
\text { Mar } 2005\end{array}$ & $\begin{array}{l}\text { Provincial administrative } \\
\text { healthcare databases }\end{array}$ & $\begin{array}{l}\text { Describe the epidemiology of asthma } \\
\text { presentations to EDs for } 3 \text { main regions } \\
\text { in the province of Alberta }\end{array}$ & $\begin{array}{l}\text { All people registered under the AHCIP at any } \\
\text { time in a given year }\end{array}$ & $\begin{array}{l}\text { ICD-9 code } 493 . x \text { or ICD-10 code J45.x as the } \\
\text { first or second diagnosis fields in the ACCS }\end{array}$ \\
\hline $\begin{array}{l}\text { Crighton et al. } 2001 \text { [20] Apr 1, } \\
1988 \text { to Mar 31, } 2000\end{array}$ & DAD database at $\mathrm{ClHI}$ & $\begin{array}{l}\text { Examine the seasonal patterns and } \\
\text { trends of asthma hospitalizations in } \\
\text { relation to age and gender }\end{array}$ & NR & ICD-9-CM code 493 \\
\hline $\begin{array}{l}\text { Ungar et al. } 2011 \text { [21] Nov 1, } \\
2000 \text { to Mar 31, } 2003\end{array}$ & $\begin{array}{l}\text { Interview data linked to } \\
\text { administrative } \\
\text { healthcare data. }\end{array}$ & $\begin{array}{l}\text { Identify factors associated with asthma } \\
\text { exacerbation causing ED visits or } \\
\text { hospitalizations related to health status, } \\
\text { socioeconomic status (SES), and drug } \\
\text { insurance }\end{array}$ & 1 to 18 years & $\begin{array}{l}\text { Physician-diagnosed asthma; ICD-9 } 493 \text { or } \\
\text { ICD-10 J45 }\end{array}$ \\
\hline $\begin{array}{l}\text { Disano et al. } \\
2010[22] \\
2003-2006\end{array}$ & $\begin{array}{l}\text { DAD database from } \\
\text { CIHI, INSQP Deprivation } \\
\text { Index, Statistics Canada } \\
\text { Community Profiles }\end{array}$ & $\begin{array}{l}\text { Examine inequalities between SES groups } \\
\text { with respect to rates of ACSC- } \\
\text { hospitalizations }\end{array}$ & $\begin{array}{l}\text { Acute care cases of } 0 \text { to } 75 \text { years; asthma in } \\
\text { children for age }<20 \text { years }\end{array}$ & NR \\
\hline Blais et al. 2009 [18] 2002 - 2004 & RAMQ database & $\begin{array}{l}\text { Compare the use of healthcare services } \\
\text { between new users of } \\
\text { budesonide/formoterol and F/S }\end{array}$ & $\begin{array}{l}\text { Asthma patients aged } 16 \text { to } 65 \text { years } \geq 1 \text { claim } \\
\text { for combination therapy in } 2002 \text { or } 2003 \text { and } \\
\text { no claims for combination therapy for } \geq 1 \text { year } \\
\text { prior to first claim }\end{array}$ & ICD-9 codes 493.0, 493.1, 493.9 \\
\hline $\begin{array}{l}\text { Rowe et al. } 2009 \text { [23] } 1 \text { Apr } \\
\text { 1999-31 Mar } 2005\end{array}$ & $\begin{array}{l}\text { ACCS and other } \\
\text { provincial databases. }\end{array}$ & $\begin{array}{l}\text { Describe the epidemiology of asthma } \\
\text { presentations to EDs made by adults in } \\
\text { the province of Alberta, Canada }\end{array}$ & Asthmatic individuals aged 18 years & ICD-9 493.x or ICD-10 J45.x \\
\hline To et al. 2008 [24] 1994 - 1998 & $\begin{array}{l}\text { DAD database from } \\
\text { CIHI, OHIP records, } \\
\text { RPDB database }\end{array}$ & $\begin{array}{l}\text { Describe the prevalence of asthma; } \\
\text { all-cause mortality; physician visits and } \\
\text { hospitalizations for asthma and all causes; } \\
\text { and seasonal and geographical variation of } \\
\text { healthcare utilization in children }\end{array}$ & Children aged 0 to 9 years & $\begin{array}{l}\text { At least } 1 \text { asthma hospitalization or } 2 \text { asthma } \\
\text { OHIP claims within } 3 \text { years }\end{array}$ \\
\hline $\begin{array}{l}\text { Lemiere et al. } \\
2007[25] \\
2001-2004\end{array}$ & $\begin{array}{l}\text { RAMQ database, } \\
\text { WRA patients }\end{array}$ & $\begin{array}{l}\text { Compare clinical characteristics and use } \\
\text { of medical resources between subjects } \\
\text { with OA, WEA, and WRA }\end{array}$ & NR & $\begin{array}{l}\text { Physician-diagnosed asthma OA, WEA, and } \\
\text { WRA }\end{array}$ \\
\hline
\end{tabular}

Examine the seasonal patterns and trends of asthma hospitalizations in sospitalizations related to health status, insurance

IIHI, INSQP Deprivation Community Profiles

Compare the use of heathcare services between new users of

Describe the epidemiology of asthma presentations to EDs made by adults province of Alberta, Canada Compare clinical characteristics and use with OA, WEA, and WRA 
Table 3 Characteristics of clinical burden studies included in the review (Continued)

\section{To et al. 2007 [26]}

1994 to 2006

HMDB database from

database;

Agha et al. 2007 [27] 1993 - 2001 DAD database at CIHI SES from the 1996 Census data

Gershon et al. 2007 [2] 1994/95 DAD from CIHI, OHIP to $2001 / 202$

Lougheed et al.

2006 [28]

$2001-2002$

Dik et al. 2006 [29] 1985 - 1998

Examine and predict

Examine socioeconomic disparities in ACS and non-ACS admissions among birth cohorts in a universal health insurance setting

Understand the burden of asthma

Assess regional differences in ED visit rates and hospitalizations for asthma

Manitoba administrative Study 14-year trends in utilization of healthcare data

physician rear trends in utilization of pare them to trends for allergic rhinitis

Sin et al. 2001 [30] FY $1992-1996$ CIHI, drug claims, physician billing, and mortality databases

Determine the impact of ICS on

rehospitalization for asthma and mortality rates in elderly patients

\section{Prospective cohort studies}

Rowe et al. 2010 [31] 2004 2005

Interviews

Describe factors associated with admission to hospital for acute asthma after ED treatment

Sin et al. 2003 [32] 1985, 1988 AHCIP data

Ungar et al. 2001 [33] May - Oct 1995

Telephone interviews a 1,3 , and 6 months,

Determine the relationship between SES and ED visits for asthma in a free access healthcare system.

Assess the cost of asthma care at the patient level in children from the perspectives of society, the Ontario Ministry of Health, and the patient.

Anis et al. 2000 [34] Sept 1, 1994 - Hospital ED, telephone Aug 311995

Rowe et al. 2007 [23] 1996-1998 interview for follow-up

Estimate the average direct cost of illness or 4 cardiorespiratory conditions

Compare ED asthma management and outcomesbetween Canada and US and telephone followup 2 weeks later

\section{Cross-sectional studies}

Boulet et al. 2008 [35] April - $\quad$ Telephone survey August 2004,

Klomp et al. 2008 [36] 2002/03 and 2003/04
Health databases in Saskatchewan
Assess the influence of current and

former smoking on self-reported asthma control and healthcare use

Describe the quality of asthma care using a set of proposed quality indicators
Children born in 1994 diagnosed with asthma before their 6 th birthday, followed up until their 12th birthday

Children born alive in Toronto during 1993-2001

Asthma patients from ON, aged 0-39 years

ED visits for asthma

Asthmatic patients, aged $\geq 65$ years, who had been hospitalized with a most responsible diagnosis of asthma in the past 5 years

Patients aged 18 to 55 years diagnosed with asthma

Children born 1985 to 1988 followed for 10 years

Patients or caregivers filling prescriptions for bronchial inhalers

ED visitors who completed follow-up interviews

Patients aged 2 to 54 years who presented with acute asthma in ED

Adults aged 18 to 54 years with physiciandiagnosed asthma for $\geq 6$ months

Saskatchewan residents who had a valid health insurance number
1 asthma hospitalization or 2 asthma physician claims within 3 years prior to age 6 years (ICD9493 or ICD-10 J45). Persistent asthma - additional claims during follow-up Remission asthma - no additional claims

The most responsible diagnosis in the $\mathrm{CH}$ DAD DB

1 DAD hospitalization record or 2 OHIP claims for asthma in a 3-year period

ICD-10 code J45.x

ICD-9-CM code 493

ICD-9 codes 493.0, 493.1, and 493.9

Patient-reported

ICD-9 code 493.x

Probable asthma - a prescription for a bronchial inhaler medication in the last month (bronchodilator or corticosteroid) and reported experiencing shortness of breath wheeze, or recurrent cough in the past

ED visit records

Patient-reported or physician-diagnosed asthma

Over 1-year period: $\geq 3$ prescriptions for antiasthma drug or $\geq 2$ physician claims (ICD-9 code 493) or $\geq 2$ hospitalization claims (ICD-9 493.x or 
Baibergenova et al. 2005 [39] April 1, 2001 to March 31, 2004

Lynd et al. 2004 [40] NR
Determine the association between demographics, access to care, SES, and need (comorbidities) with actual family physician costs

Ministry of Health administrative databases

\section{Case-control study}

Suissa et al. 2002 [41] 1975 - 1997 Saskatchewan Health $\mathrm{DB}$

\section{Health economic analysis}

Seung et al. 2005 [42] 2004

NACRS at $\mathrm{CIHI}, \mathrm{OCCl}$, MOHLTC billing
Determine whether excessive use of $S A B A$, in conjunction with underuse of ICS, would be a marker for poorly controlled asthma and excessive use of

Examine the pattern and strength of seasonal fluctuations in ED visits due to asthma

Assess the association between SES and SABA use, controlling for asthma severity

Assess whether regular use of ICS prevents asthma hospitalizations

Determine the use of urgent care resources and annual costs for the uncontrolled asthmatic population in Canada healthcare resources
ICD-10 J45.x) or $\geq 1$ claim for physician services or hospitalization for asthma plus $\geq 1$ pharmacy claim for an antiasthma drug

Survey respondents aged $\geq 25$ years

Self-reported

政 MOHLTC

Asthma patients aged 5 to 50 years for whom Patients filling SABA prescriptions; for

$\geq 1$ prescription for a SABA was filled in 1995 hospitalizations, ICD-9 code 08 (diseases of the respiratory system)

Asthma patients with ED visits for asthma or ICD-9 code 493.x or ICD-10 J45.0-J45.9 status asthmaticus

Asthmatic patients aged 19 to 50 years

residing in the Greater Vancouver Regiona

District of British Columbia

Source cohort: subjects aged 5-44 years receiving $\geq 3$ prescriptions of an antiasthm medication in any 1-year period Full cohort: all subjects with $\geq 1$ year follow-up, irrespective of whether they were admitted to hospital for asthma during the baseline year

Primary discharge diagnosis of asthma (ICD-9 codes 493.0, 493.1, or 493.9)

ICD-9 Code 493

ACCS=ambulatory care classification system, ACSC=ambulatory care-sensitive conditions, AHCIP=Alberta Healthcare Insurance Plan, ClHI=Canadian Institute for Health Information, CNPHS=Canadian National Population Health Survey, DAD=Discharge Abstract Database, ED=emergency department, HMDB=Hospital Morbidity Database, ICS=inhaled corticosteroid, ICD=International Classification of Diseases, LTRA=leukotriene receptor antagonist, MOHLTC=Ministry of Health and Long Term Care, NACRS=National Ambulatory Care System, NR=not reported, OA= occupational asthma, OCCl=Ontario Case Costing Initiative, OHIP=Ontario Health Insurance Plan, RAMQ=Régie de l'assurance maladie du Québec, RPDB=Registered Persons Database, SES=socioeconomic status, WEA=work-exacerbated asthma, WRA=work-related asthma. 
Table 4 Rate of hospitalizations for asthma patients in Canada

\begin{tabular}{|c|c|c|c|c|c|}
\hline \multirow[t]{2}{*}{ Study } & \multirow[t]{2}{*}{ Number of patients } & \multirow[t]{2}{*}{ Patient descriptor } & \multirow[t]{2}{*}{ Year } & \multicolumn{2}{|c|}{ Hospitalizations for asthma } \\
\hline & & & & $\begin{array}{l}\text { Per patient } \\
\text { per year }\end{array}$ & $\begin{array}{l}\text { Per } 1000 \text { patients per } \\
\text { year }\end{array}$ \\
\hline \multicolumn{6}{|l|}{ Children } \\
\hline \multirow[t]{4}{*}{$\begin{array}{l}\text { Blais et al. } \\
2011[43]\end{array}$} & \multirow[t]{2}{*}{7,494} & $\begin{array}{l}\geq 1 \text { exacerbations in the year prior to treatment initiation, } \\
\text { ICS }\end{array}$ & \multirow[t]{4}{*}{ 1998-2005 } & 0.03 & \\
\hline & & $\begin{array}{l}\geq 1 \text { exacerbations in the year prior to treatment initiation, } \\
\text { LTRA }\end{array}$ & & 0.06 & \\
\hline & \multirow[t]{2}{*}{19,861} & No exacerbation in the year prior to treatment initiation: ICS & & 0.005 & \\
\hline & & $\begin{array}{l}\text { No exacerbation in the year prior to treatment initiation: } \\
\text { LTRA }\end{array}$ & & 0.003 & \\
\hline $\begin{array}{l}\text { Ungar et al. } \\
2011[21]\end{array}$ & 490 & Asthmatic children & $2000-2003$ & $0.25 \S$ & \\
\hline \multirow[t]{4}{*}{ To et al. 2008 [24] } & 56,737 & $0-2$ years & \multirow[t]{4}{*}{ 1998/1999 } & & 86.7 \\
\hline & 99,163 & 3-5 years & & & 27.3 \\
\hline & 141,305 & 6-9 years & & & 10.9 \\
\hline & 297,205 & Overall & & & 30.9 \\
\hline \multirow[t]{3}{*}{ To et al. 2007 [26] } & \multirow[t]{3}{*}{34,216} & Persistent asthma & \multirow[t]{3}{*}{ 1994-2006 } & & $63^{*}$ \\
\hline & & Remission asthma & & & $39^{*}$ \\
\hline & & Overall & & & $52^{*}$ \\
\hline $\begin{array}{l}\text { Ungar et al. } \\
2001[33]\end{array}$ & 339 & Asthma children & 1995 & 1 & \\
\hline \multicolumn{6}{|l|}{ Adults } \\
\hline \multirow{2}{*}{$\begin{array}{l}\text { Sadatsafavi et al. } \\
2010[10]\end{array}$} & \multirow[t]{2}{*}{158,516} & Narrow asthma definition€ & \multirow[t]{2}{*}{$1996-2000$} & 0.016 & \\
\hline & & Broad asthma definition $¥$ & & 0.03 & \\
\hline \multirow{2}{*}{$\begin{array}{l}\text { Lemiere et al. } \\
2007[25]\end{array}$} & \multirow[t]{2}{*}{351 (WEA: 145, OA: 206) } & WRA & \multirow[t]{2}{*}{$2001-2003$} & $0.04(0.2)$ & \\
\hline & & NWRA & & $0.008(0.7)$ & \\
\hline \multirow{2}{*}{$\begin{array}{l}\text { Anis et al. } \\
2001[38]\end{array}$} & 4,671 & Appropriate uset & \multirow[t]{2}{*}{1995} & $0.07(0.34)$ & \\
\hline & 763 & Inappropriate useł & & $0.11(0.42)$ & \\
\hline \multicolumn{6}{|l|}{ All ages } \\
\hline \multirow{3}{*}{$\begin{array}{l}\text { Disano et al. } \\
2010 \text { [22] }\end{array}$} & \multirow[t]{3}{*}{ NR } & High SES & \multirow[t]{3}{*}{$2003-2006$} & & $1.61^{* *}$ \\
\hline & & Average SES & & & $1.95^{* *}$ \\
\hline & & Low SES & & & $2.7^{* *}$ \\
\hline \multirow[t]{2}{*}{$\begin{array}{l}\text { Klomp et al. } \\
2008 \text { [36] }\end{array}$} & \multirow[t]{2}{*}{$\begin{array}{l}24,616(24,180 \text { of whom were still alive and living in the } \\
\text { region the following year) }\end{array}$} & \multirow[t]{2}{*}{ Asthma patients } & $\begin{array}{l}2002 / 2003 \text { and } \\
2003 / 2004\end{array}$ & & \multirow[t]{2}{*}{10.9} \\
\hline & & & $2001-2002$ & & \\
\hline
\end{tabular}

To et al. 2007 [26] 34,216 
Table 4 Rate of hospitalizations for asthma patients in Canada (Continued)

\begin{tabular}{|c|c|c|c|c|}
\hline $\begin{array}{l}\text { Lougheed et al. } \\
2006[28]\end{array}$ & $\begin{array}{l}574,304 \text { children and 1,194,095 } \\
\text { adults in Ontario }\end{array}$ & $\begin{array}{l}\text { Patients with an ED disposition diagnosis of asthma in a } \\
\text { stratified sample of } 16 \text { hospitals }\end{array}$ & & $\begin{array}{l}108(10.8 \%) \text { children; } 69 \\
(6.9 \%) \text { adults }\end{array}$ \\
\hline \multirow{2}{*}{$\begin{array}{l}\text { Suissa et al. } \\
2002[41]\end{array}$} & 30,569 & Source cohortt† & 1975-1997 & 48 \\
\hline & 4,673 & Full cohort㧊 & & 42.4 \\
\hline $\begin{array}{l}\text { Seung et al. } \\
2005[42]\end{array}$ & NR & Asthma patients & 2004 & $1.43^{* *}$ \\
\hline
\end{tabular}

\$Calculated as 124 hospitalizations for 490 patients.

${ }^{*}$ Calculated as the rate per 100 patients $\times 10$.

${ }^{*}$ Calculated as (the rate per 100,000 patients) / 100 .

$€$ Narrow asthma definition: ICD-9 493.x.

¥Broad asthma definition: visits for an asthma-related diagnosis; hospitalizations with asthma among the discharge diagnoses.

\#Broad asthma de

tAppropriate use (low-dose SABA + high-dose ICS).

t+Source cohort: subjects 5-44 years receiving $\geq 3$ prescriptions of an anti-asthma medication (beclomethasone, budesonide, epinephrine bitartrate, fenoterol, flunisolide, ipratropium bromide, isoproterenol, ketotifen,

t+Source cohort: subjects $5-44$ years receiving $\geq 3$ prescriptions of an anti-asthma medication (beclomethasone, budesonide, epinephrine bitartrate, fenoterol, flunisolde
metaproterenol, nedocromil, procaterol, salbutamol, sodium cromoglycate, terbutaline, triamcinolone acetate, or any compound of theophylline) in any 1 year period.

\#¥Full cohort: all subjects with at least 1 year follow up, irrespective of whether or not they were admitted to hospital for asthma during the baseline year.

NWRA=non-work-related asthma; WRA=work-related asthmo. 
reduction in the rate of hospital admissions for asthma and a $39 \%$ reduction in the rate of readmissions for the cohort with more severe asthma who had been previously hospitalized for the condition during the 1-year baseline period. The study investigators concluded that their findings emphasize the importance of regular use of inhaled corticosteroids to avoid hospitalizations.

In a retrospective cross-sectional study of asthma patients aged 5-54 years using health databases in Saskatchewan, Klomp et al. [36] found that, in 2002-03 and 2003-04, the hospitalization rate for asthma was 10.9 per 1000 patients per year.

Agha et al. [27], using data on hospital admissions from the Dischrage Abstract Database of the Canadian Institute for Health Information, reported 8,583 asthma hospitalizations among 255,284 pediatric patients (a rate of 33.6 in 1000 patients) born between 1993 and 2000 in Toronto.

A significantly lower rate was reported in Canada by Seung et al. [42], who cited figures reported by the Public Health Agency of Canada of 143 asthma-related hospitalizations per 100,000 adult and pediatric patients, or 1.43 in 1000, in 1998 (with an additional 3.7 per 1000, many of whom had underlying asthma, hospitalized for influenza/pneumonia).

Higher rates were reported for hospital admissions of patients who initially presented to the emergency department (ED). Lougheed et al. [28] reported that $6.9 \%$ of adults and $10.8 \%$ of children who presented to the ED with asthma were admitted to the hospital.

According to the results of a study based on interviews with parents, $25 \%$ of the pediatric study population (124 of 490 patients) had been hospitalized for asthma in the previous 12 months [21]. In a large study utilizing data from Quebec administrative databases, children aged 5 to 15 years with at least 1 exacerbation in the year prior to treatment initiation with ICS or leukotriene receptor antagonists (LTRA) had higher rates of hospitalizations than those with no exacerbation in the previous year (0.03 vs. 0.005 hospitalizations per patient per year in the ICS group and 0.06 vs. 0.003 per patient per year in the LTRA group) [43]. The proportion of prescribed days covered was significantly higher in the LTRA group than in the ICS group (52\% vs. $34 \%$ ) [43].

In a study of all Ontario babies born during the year 1994 who were diagnosed with asthma before their sixth birthday, there was a decreasing trend in hospitalization rates with age, from 86.7 per 1000 patients per year in the 0 to 2 years age group to 27.3 per 1000 patients for those aged 3 to 5 years and 10.9 per 1000 for those aged 6 to 9 years. These investigators also found that children with persistent asthma had more than one and a half times higher hospitalization rates compared with patients whose asthma was in remission (63 per 1000 patients vs. 39 per 1000 patients per year) [26].
In another Ontario-based study that examined asthma seasonality and hospitalizations by gender and age group over a 12-year period, results of spectral analysis revealed that hospitalization rates for children with asthma were highest in September and October each year across the 12-year period, with a 2 to 3-times higher rate of hospitalizations in boys (180 per 100,000) than in girls under the age of 9 years [20]. However, among children older than 9 years, female hospitalizations exceeded those of males [20].

The large variations in reported rates of hospitalizations may be due to variations in ED visit rates and/or hospital admission percentages [28]. Hospital admissions appear to follow a bimodal age distribution pattern, with the very young and the elderly more likely to be admitted [28]. Other factors that can drive up rates of hospitalization in particular regions or among specific populations are higher disease prevalence, greater disease severity, multiple comorbidities, and barriers to care associated with socioeconomic status [27].

\section{ED visits}

The number of asthma emergency visits varied by age, type of treatment, social status, and living area (urban/ non-urban). Table 5 summarizes ranges and mean numbers of annual ED visits for asthma, as reported in the included studies. According to several studies, both children and adults with asthma averaged less than $1 \mathrm{ED}$ visit per patient per year $[21,23,28]$. ED visit rates were significantly higher in women than in men and, overall, the rate of ED visits increased with age [28].

In a study investigating the impact of appropriate use (according to the 1999 Canadian asthma consensus report and the National Heart, Lung and Blood Institute Guidelines for the Diagnosis and Management of Asthma) and compliance with asthma medications in adults, the rate of ED visits for asthma was twice as high for patients not using asthma medication appropriately (high-dose SABA plus low-dose ICS) than for those using it appropriately (lowdose SABA plus high-dose ICS) [38].

Rosychuk et al. [19] examined trends in asthmarelated ED visits by more than 45,000 children aged $<18$ years during the period from April 1999 to March 2005 and did not observe decreased ED presentation rates over time, despite improvements in treatment and availability of guidelines. The standardized rates remained stable over time, with 21.1 visits occurring per 1000 patients in 1999/2000 versus 19.8 per 1000 in 2004/2005.

Sin et al. $[30,44]$ reported that elderly asthmatic patients using ICS post-discharge from hospital were $29 \%$ less likely to be readmitted to hospital for asthma and $39 \%$ less likely to experience all-cause mortality compared with those who did not receive ICS post-discharge 
Table 5 Annual number of ED visits for asthma, per patient, in Canada

\begin{tabular}{|c|c|c|c|c|}
\hline \multirow[t]{2}{*}{ Reference } & \multirow{2}{*}{$\begin{array}{l}\text { Number } \\
\text { of } \\
\text { patients }\end{array}$} & \multirow[t]{2}{*}{ Descriptor } & \multicolumn{2}{|c|}{$\begin{array}{l}\text { Annual mean number (SD) of ED visits per patient for } \\
\text { asthma (range) }\end{array}$} \\
\hline & & & From & To \\
\hline \multicolumn{5}{|l|}{ Children } \\
\hline $\begin{array}{l}\text { Blais et al. } \\
2011 \text { [43] }\end{array}$ & 27,355 & $\begin{array}{l}\text { Children, 5-15 years, on ICS or LTRA therapy, by \# of } \\
\text { exacerbations in the previous year, 1998-2005 }\end{array}$ & $\begin{array}{l}0.04^{*} \text { (on LTRA, no exacerb. } \\
\text { in the previous year) }\end{array}$ & $\begin{array}{l}0.32^{*} \text { (on ICS, } 1+\text { exacerb. } \\
\text { in the previous year) }\end{array}$ \\
\hline $\begin{array}{l}\text { Lougheed et al. } \\
2006[28]\end{array}$ & 4,674 & Ontario patients, $<20$ years, 2001-2002 & $13.6[8.7 \text { to } 25.2]^{* *}$ & \\
\hline $\begin{array}{l}\text { Sin et al. } \\
2003[32]\end{array}$ & 90,845 & Children, 0-10 years, 1985-1988, by SES & $6[0 \text { to } 31]^{* *}$ (very poor) & $7[0 \text { to } 34]^{* *}$ (non-poor) \\
\hline $\begin{array}{l}\text { Ungar et al. } \\
2001[33]\end{array}$ & 339 & Children with asthma, <15 years, Ontario, 1995 & $0.8^{*}$ & \\
\hline \multicolumn{5}{|l|}{ Adults } \\
\hline $\begin{array}{l}\text { Sin et al. } \\
2001[44]\end{array}$ & & elderly asthmatic, by ICS therapy & $1(1.2)^{*}$ (not using ICS) & $1.5(1.3)^{*}$ (using ICS) \\
\hline $\begin{array}{l}\text { Rowe et al. } \\
2009 \text { [45] }\end{array}$ & 48,942 & Adults, $1999 / 2000$ to $2004 / 2005$ & $6.7^{* *}(2004 / 2005)$ & $9.7^{* *}(1999 / 2000)$ \\
\hline $\begin{array}{l}\text { Lemiere et al. } \\
2007[25]\end{array}$ & 351 & Adults, work-related asthma, 2001-2004 & $0.2(0.7)^{*}(\mathrm{NWRA})$ & $0.3(0.8)^{*}(\mathrm{WRA})$ \\
\hline $\begin{array}{l}\text { Lougheed et al. } \\
2006[28]\end{array}$ & 3,993 & Adults, $\geq 20$ years, 2001-2002 & $3.9[1.7 \text { to } 10.1]^{* *}$ & \\
\hline $\begin{array}{l}\text { Anis et al. } \\
2001[38]\end{array}$ & 5,434 & Adults, use of SABA+ICS, 1995 & $\begin{array}{l}0.04(0.26)^{*} \text { (appropriate } \\
\text { use }) \text { ) }\end{array}$ & $\begin{array}{l}0.08(0.33)^{*} \text { (inappropriate } \\
\left.\text { use } \int\right)\end{array}$ \\
\hline $\begin{array}{l}\text { Rowe et al. } \\
2007 \text { [23] }\end{array}$ & 3,031 & Canada and US ED visits, 1996-1998 & $0(0-3) \S(U S)$ & $1(0-3)^{\S}$ (Canada) \\
\hline $\begin{array}{l}\text { Baibergenova } \\
\text { et al. } 2005 \text { [39] }\end{array}$ & 73,566 & Adult, Ontario, 2001-2004 & $0.45^{\dagger}$ & \\
\hline \multicolumn{5}{|l|}{ All ages } \\
\hline $\begin{array}{l}\text { Rosychuk et al. } \\
2010 \text { [19] }\end{array}$ & 21,700 & Asthma patients, Alberta, 2004-2005 & $6.9(6.6-7.0)^{* * *}($ Calgary $)$ & $15.1(15.1-15.9)^{* * *}(\mathrm{NMU})$ \\
\hline
\end{tabular}

*Per patient.

**Mean [range] per 1000 patients.

***Mean $(95 \% \mathrm{Cl})$.

§Median (IQR).

SAppropriate use (low-dose SABA + high-dose ICS); Inappropriate use (high-dose SABA + low-dose ICS).

†Calculated from 99,054 ED visits due to asthma were made by 73,566 adults.

ICS=inhaled corticosteroid, LTRA=leukotriene receptor antagonist, NMU= non-major urban areas, NWRA=non-work-related asthma, SABA=short-acting $\beta$-agonist,

WRA =work-related asthma.

over a 1-year follow-up period. When age, sex, comorbidity, and use of other antiasthma medications were controlled for, ICS use was associated with a $32 \%$ relative rate reduction for recurrent hospitalization or all-cause mortality (95\% CI 23\%-39\%). Among patients who received at least 1 prescription for ICS within 1 year prior to the index hospitalization, the use of ICS 90 days postdischarge was associated with a $41 \%$ decrease in recurrent asthma-related hospitalizations or deaths compared with non-use of ICS (95\% CI 32\%-49\%).

Sin et al. [32] also reported on ED visits in children born in Alberta between 1985 and 1988, stratified by SES, and found that very poor children were $23 \%$ more likely to have had an ED visit for asthma compared with children from non-poor families (RR 1.23; 95\% CI 1.14 - 1.33). Very poor children had a similar risk of having an asthma-related ED visit as poor children (RR 0.97; 95\% CI 0.91 - 1.04).

\section{Physician visits}

Studies that reported rates of asthma-related physician visits are summarized in Table 6 . In a population-based study evaluating 14-year trends in Manitoba in utilization of physician resources for asthma, Dik et al. [29] found that, between the period 1985-1988 and 1994-1998, the greatest increases in prevalence and incidence of physician visits for asthma occurred in the youngest age groups, while in adults the prevalence and incidence changed little with time. However, the average rate of physician visits for asthma decreased from 1.66 visits per patient-year in $1985-1988$ to 1.40 in $1989-1993$, and further to 1.16 visits per patient-year in 1994-1998.

More former or current smokers than non-smokers visited their physician [35], as did patients with workrelated asthma vs. non-work-related asthma [25] and patients inappropriately using their asthma medication 
Table 6 Rate of physician visits in Canada

\begin{tabular}{|c|c|c|c|c|}
\hline Study & Number of patients & Patient descriptor & Year & Physician visits for asthma \\
\hline \multicolumn{5}{|l|}{ Children } \\
\hline \multirow[t]{4}{*}{ To et al. 2008 [24] } & 56,737 & $0-2$ years & 1998/1999 & 2.2 \\
\hline & 99,163 & 3-5 years & & 1.1 \\
\hline & 141,305 & 6-9 years & & 0.8 \\
\hline & 297,205 & Overall & & 1.2 \\
\hline \multirow[t]{2}{*}{ Ungar et al. 2001 [33] } & 339 & GP & 1995 & 3.6 \\
\hline & & Respiratory specialist & & 2.1 \\
\hline \multicolumn{5}{|l|}{ Adults } \\
\hline \multirow[t]{3}{*}{ Boulet et al. 2008 [35] } & 514 & Non-smoker & 2004 & $43 \%$ had $\geq 1$ \\
\hline & 268 & Former smoker & & $49 \%$ had $\geq 1$ \\
\hline & 108 & Current smoker & & $47 \%$ had $\geq 1$ \\
\hline \multirow[t]{2}{*}{ Lemiere et al. 2007 [25] } & 351 (WEA: 145, OA: 206) & WRA & $2001-2003$ & $4.1(4.3)$ \\
\hline & & NWRA & & $1.2(1.7)$ \\
\hline \multirow[t]{2}{*}{ Sadatsafavi et al. 2010 [10] } & 158,516 & Narrow asthma definition & $1996-2000$ & 1.86 \\
\hline & & Broad asthma definition & & 3.85 \\
\hline Iron et al. 2003 [37] & $230^{*}$ & Asthma patients & 1994/1995 & $4.3^{* *}$ \\
\hline \multirow[t]{2}{*}{ Sin et al. 2001 [44] } & 6,254 & No ICS (elderly) & 1992-1996 & $3.9(2.2)$ \\
\hline & & ICS (elderly) & & $4(2.2)$ \\
\hline \multirow[t]{2}{*}{ Anis et al. 2001 [38] } & 4,671 & Appropriate use & 1995 & 14.9(15.9) \\
\hline & 763 & Inappropriate useł & & 16.7(19.3) \\
\hline Anis et al. 2000 [34] & 733 & Physician visits in ED & 1994-1995 & $1.0(1.3)$ \\
\hline \multirow[t]{2}{*}{ Blais et al. 2009 [18] } & 1264 & BUD/FORM & $2002-2004$ & $7.5(7.4)$ \\
\hline & 1264 & $\mathrm{FP} / \mathrm{SM}$ & & $7.3(7)$ \\
\hline \multicolumn{5}{|l|}{ All ages } \\
\hline \multirow[t]{8}{*}{ Gershon et al. 2007 [2] } & NR & All-cause claims & 1994/1995 & 13.2 \\
\hline & & & 1995/1996 & 12.5 \\
\hline & & & 1996/1997 & 12.0 \\
\hline & & & 1997/1998 & 12.1 \\
\hline & & & 1998/1999 & 11.9 \\
\hline & & & 1999/2000 & 11.6 \\
\hline & & & $2000 / 2001$ & 11.5 \\
\hline & & & $2001 / 2002$ & 11.2 \\
\hline
\end{tabular}

$\S$ Per patient per year, mean (SD).

*Asthma patients, calculated as $6 \%$ of 3830 NPHS responders.

**Median.

†Appropriate use (low-dose SABA + high-dose ICS).

flnappropriate use (high-dose SABA + low-dose ICS)

$B U D / F O R M=$ budesonide/formoterol, FP/SM=fluticasone propionate/salmeterol, GP=general practitioner, ICS=inhaled corticosteroid, NR=not reported, NWRA=non-work-

related asthma, WRA=work-related asthma.

[38]. Among elderly patients, the rate of physician visits for asthma was not influenced by treatment with ICS [44].

Children in an Ontario-based study who were born in 1994 and diagnosed with asthma before age 6, and whose asthma persisted until age 11 (as determined by the presence of claims for physician and/or hospital visits between the ages of 6 and 11), had a higher rate of physician visits than those in remission (60 vs. 46.9 visits per 100 patients per year) [26].

\section{Medication prescriptions}

Lynd et al. [40] reported that $27 \%$ of patients receive oral corticosteroids, $17 \%$ use no ICS, $47 \%$ receive less than 4 ICS canisters per year, 29\% use 5 to 12 canisters, and $8 \%$ use more than 12 ICS canisters per year. 
Based on available data, children received more prescriptions per patient per year than adults $[11,21,38]$. Patients with inappropriate use of asthma medications (ie, those who were non-adherent to guidelines recommended in the 1999 Canadian asthma consensus report and the National Heart, Lung and Blood Institute Guidelines for the Diagnosis and Management of Asthma) received more than double the number of prescriptions per patient per year (mean [SD] 7.5 [4.9]) compared with those who used asthma medication appropriately (mean [SD] 3.3 [1.9]) [38].

\section{Economic burden studies Overview}

Ten studies evaluated the economic burden of asthma in Canada (5 cohort studies, 4 cross-sectional, and 1 economic analysis). Costs in the economic analysis were calculated for $1,350,871$ persons, based on the $1998 / 1999$ estimate that $57 \%$ of $2,389,085$ persons aged $\geq 4$ years had uncontrolled asthma.

More than $80 \%$ of these studies met the STROBE criteria for appropriate quality discussion. Most studies clearly reported the study design (90\%), setting (100\%), participants (90\%), and statistical methods employed (70\%). However, less than half reported on potential sources of bias and confounding factors or how missing data was handled and how loss to follow-up was addressed in both the methods and results sections or sensitivity analyses conducted. Most studies $(60 \%)$ gave the source of funding and the role of the funders for their study (Table 1).

Asthma cases were identified using ICD codes or clearly stated diagnosis, retrospective physician visits, hospitalizations for asthma, and/or asthma medication prescriptions filled or patient self-report of asthma diagnosis or symptoms. There was available evidence on both the direct and indirect components of the economic burden of asthma in Canada. The overall burden varied based on whether studies reported costs from the perspective of an individual patient with asthma or costs at the population level. Few Canadian studies reported a cost per episode of acute asthma, and no studies reported the cost per patients overall. Five studies reported data on the direct costs of asthma at the patient-level. Three of these studies reported asthma costs per asthma patient [10,24,37], while 2 studies reported asthma costs per acute asthma episode [34,42]. Three studies reported population-level direct costs for asthma $[10,24,42]$. Study characteristics are presented in Table 7.

\section{Key findings on economic burden}

All costs reported in this section are in 2011 Canadian dollars.

\section{Patient-level direct costs}

Based on data from administrative databases in British Columbia, average total annual direct cost estimates in the general population ranged from $\$ 366.17$ to $\$ 490.88$ per asthma patient (Table 8) [10].

Ungar and colleagues [33] estimated the total cost of asthma in children aged $0-14$ years in Ontario to be $\$ 883.48$ per child from the healthcare perspective (Table 8). Adjusted annual societal costs per patient (1995 Canadian dollars) ranged from $\$ 1,122$ in children aged 414 years to $\$ 1,386$ in children younger than 4 years. From the Ministry of Health perspective, adjusted annual costs per patient were $\$ 663$ in children over 4 years and $\$ 904$ in younger children. Adjusted annual costs from the patient perspective were $\$ 132$ in children over 4 years and $\$ 129$ in children under 4 years.

During the period from 1996 - 2000, average hospitalization costs ranged from $\$ 67.90$ to $\$ 136.87$ per patient per year in the general population in British Columbia (aged 5 to 55 years), depending on the definition used to categorize asthma-related hospitalizations [10]. The estimated average annual hospitalization cost for asthma in children was \$682.21 per patient in Ontario [33].

Sadatsafavi et al. [10] reported that ED visits made by asthma patients in the general population could cost the healthcare system anywhere between \$66.35 and \$122.09 per visit, depending on the asthma definition used. The reported range of average costs for ED visit per acute asthma episode was $\$ 209.48$ to $\$ 274.48$ [10,33]. Ungar and colleagues [33] estimated the average annual cost for ED visits in children to be $\$ 15.68$.

The average costs for physician visits per acute asthma episode were estimated to range from $\$ 31.72$ [34] in an economic modeling study using prospectively collected resource utilization data $(9 / 1 / 94$ to $8 / 31 / 95)$ from hospital emergency department visitors to $\$ 31.91$ in the economic analysis by Seung and Mittmann [42]. Average costs of $\$ 98.02$ and $\$ 70.57$ annually per pediatric patient were reported for family physician and specialist visits, respectively, in the prospective study by Ungar et al. [33]. Although the cost per respiratory specialist visit was higher than the cost per family physician visit ( $\$ 105.40$ vs. $\$ 51.40$ for the first visit and $\$ 23.10$ vs. $\$ 16.25$ for an additional visit), nearly twice as many patients (271, or $80 \%$ ) reported visiting a family physician, at an average annual use of 3.6, compared with a respiratory specialist (141, or $42 \%$ of patients), at an average annual use of 2.1 [33]. A study conducted in Ontario demonstrated that outpatient claim costs for persons with asthma exceeded those for persons without asthma by about $\$ 200$ per person per year [2].

With regard to asthma medication prescriptions, the administrative database study from British Columbia estimated the average annual cost for asthma medication in the general population to be $\$ 231.92$ per patient [10]. 
Table 7 Characteristics of economic burden studies included in the review

\begin{tabular}{|c|c|c|c|c|}
\hline $\begin{array}{l}\text { Reference/Study } \\
\text { period }\end{array}$ & Data source & Study objective & Inclusion criteria & Asthma definition \\
\hline \multicolumn{5}{|c|}{ Retrospective cohort studies } \\
\hline \multirow{4}{*}{$\begin{array}{l}\text { Sadatsafavi et al. } \\
2010 \text { [10] } 1996-2000\end{array}$} & \multirow{4}{*}{$\begin{array}{l}\text { Administrative } \\
\text { healthcare data }\end{array}$} & \multirow{4}{*}{$\begin{array}{l}\text { Determine direct medical costs of asthma-related } \\
\text { healthcare in British Columbia }\end{array}$} & Aged 5 to 55 years & \multirow{4}{*}{$\begin{array}{l}\text { Narrow definition: ICD-9 code } 493 . x \text { Broad definition: visits for } \\
\text { an asthma-related diagnosis; hospitalizations with asthma } \\
\text { among the discharge diagnoses }\end{array}$} \\
\hline & & & $\geq 4$ asthma prescriptions in 1 year & \\
\hline & & & $\geq 1$ asthma hospitalization & \\
\hline & & & $\geq 2$ physician visits for asthma & \\
\hline $\begin{array}{l}\text { Malo et al. } 2008[46] \\
1988-2002\end{array}$ & $\begin{array}{l}\text { Administrative } \\
\text { healthcare data, }\end{array}$ & $\begin{array}{l}\text { Assess direct costs of CLI and CFI for OA and their } \\
\text { association with selected variables }\end{array}$ & $\begin{array}{l}\text { Subjects receiving compensation } \\
\text { for OA }\end{array}$ & NR \\
\hline $\begin{array}{l}\text { To et al. } 2008[24] \\
1994-1998\end{array}$ & $\begin{array}{l}\text { DAD database from } \\
\text { CIHI, OHIP records, } \\
\text { RPDB database }\end{array}$ & $\begin{array}{l}\text { Describe prevalence of asthma, all-cause mortality, } \\
\text { physician visits, and hospitalizations for asthma and all } \\
\text { causes; seasonal and geographical variation of health- } \\
\text { care utilization in children }\end{array}$ & Children aged $0-9$ years & $\begin{array}{l}\geq 1 \text { asthma hospitalization or } 2 \text { asthma OHIP claims within } 3 \\
\text { years }\end{array}$ \\
\hline
\end{tabular}

\section{Prospective cohort studies}

Ungar et al. 2001 [33] Telephone Assess cost of asthma care at the patient level in

Ministry of Health, and the patient

Anis et al. 2000 [34] 2 hospital EDs in

Estimate average direct cost of illness for 4

Patients or caregivers filling

Probable asthma - a prescription for a bronchial inhaler

prescriptions for bronchial inhalers medication in the last month (bronchodilator or corticosteroid) and reported experiencing shortness of breath, oid) and reported experiencing shortness

ED visitors who completed

ED visit records

Sept 1, 1994 - Aug Saint John, NB.

cardiorespiratory conditions

follow-up interviews

tolephone in follow-up

\section{Cross-sectional studies}

Kohen et al. 2010

NLSCY

Examine associations between asthma and school

[47] Fall 1998 and

Spring 1999

Boulet et al. 2008

[35] April - August

2004

Telephone survey functioning

Individuals aged 7-15 years with complete data on the measures of interest

Assess influence of current and former smoking on self- Adults aged 18-54 years with reported asthma control and healthcare use

physician-diagnosed asthma for

$$
\geq 6 \text { months }
$$

Survey respondents aged $\geq 25$ years consenting to share $\mathrm{HC}$

Determine the association between demograph

1994/1995

with OHIP

actual family physician costs

number and responses with

MOHLTC

Thanh et al. 2009 [48] CCHS

2005

To estimate the cost of asthma-related productivity loss days due to absenteeism and presenteeism* in Alberta

years

\section{Health economic analysis}

Seung et al. 2005 NACRS at $\mathrm{CIH}$,

[42] $2004 \quad$ OCCl, MOHLTC billing

Determine the use of urgent care resources and the

annual costs of the uncontrolled asthmatic population

NR in Canada

\section{* absenteeism=absent from work, presenteeism=at work but not fully functioning.}

$\mathrm{CCHS}=$ Canadian Community Health Survey, $\mathrm{CFI}=$ compensation for functional impairment, $\mathrm{CLI}=$ compensation for loss of income, $C N P H S=C a n a d i a n$ National Population Health Survey, $H C=$ health card, MOHLTC=Ministry of Health and Long Term Care, NLSCY= National Longitudinal Survey of Children and Youth, OA=occupational asthma, OHIP=Ontario Health Insurance Plan, SES=socioeconomic status.

Past-year wheezing or whistling in the chest and regular use of inhalers

Patient report of physician-diagnosed asthma

Self-reported

Patient report of an asthma diagnosis

ICD-9 code 493 
Table 8 Summary of studies that reported patient-level total direct costs for asthma

\begin{tabular}{|c|c|c|c|c|}
\hline Reference/Study period & Age group & Patient group & Average total annual cost per patient & Inflated 2011 \$CAD \\
\hline \multicolumn{5}{|l|}{ Retrospective cohort studies } \\
\hline \multirow{2}{*}{$\begin{array}{l}\text { Sadatsafavi et al. } 2010 \text { [10] } \\
\text { Apr } 1996 \text { - Mar } 2000\end{array}$} & \multirow[t]{2}{*}{$5-55$ yrs } & Narrow asthma definition & $\$ 331.15$ & $\$ 366.17$ \\
\hline & & Broad asthma definition & $\$ 443.93$ & $\$ 490.88$ \\
\hline \multirow[t]{5}{*}{ To et al. 2008 [24] 1994 - 1998} & \multirow[t]{5}{*}{$0-9$ yrs } & 1994/1995 & $\$ 535.9$ & $\$ 646.95$ \\
\hline & & 1995/1996 & $\$ 458.3$ & $\$ 553.27$ \\
\hline & & 1996/1997 & $\$ 392.6$ & $\$ 473.95$ \\
\hline & & 1997/1998 & $\$ 366.3$ & $\$ 442.20$ \\
\hline & & 1998/1999 & $\$ 332.9$ & $\$ 401.88$ \\
\hline \multirow[t]{3}{*}{ Ungar et al. 2001 [33] May - Oct 1995} & \multirow[t]{3}{*}{$0-14$ yrs } & Societal & $\$ 1,079$ & $\$ 1,410.17$ \\
\hline & & MOHLTC & $\$ 676$ & $\$ 883.48$ \\
\hline & & Patient & $\$ 76$ & $\$ 99.33$ \\
\hline
\end{tabular}

MOHLTC, Ministry of Health and Long Term Care.

Ungar et al. [33] estimated the average annual costs for medication per patient in children to be $\$ 352.87$ from the societal perspective and $\$ 86.26$ (2011 \$CAD) from the patient perspective. Estimated average medication costs per acute asthma episode ranged from $\$ 5.29$ to $\$ 629.39$ in these studies [10,33].

\section{Population-level direct costs}

The 1998-1999 healthcare cost for asthmatic children in Ontario (\$120 million, or \$227.1 - \$640.3 per child per year, depending on age group) was considerably higher than the total asthma cost for the general population (all ages) of British Columbia during the period $1996-2000$ ( $\sim 41.8$ million, or \$331 per patient per year) (Table 9) $[10,24]$.

Based on data from administrative healthcare databases (April 1996 through March 2000), the total annual population-level asthma cost estimates in the general population in British Columbia ranged from $\sim \$ 46.3$ million to $\$ 62.0$ million, depending on the definition of asthma used [10]. Between $\sim 8.5$ million and $~ 17.2$ million of that was spent on asthma-related hospitalizations, $\sim 8.4$ million to $\sim 15.5$ million on physician/ED visits, and $\sim 15.4$ million to $\sim 29.3$ million on asthma medications [10]. Medication costs represented the bulk (63.9\%) of the total cost, hospitalizations/ED visits comprised $17.8 \%$, and physician visits accounted for $18.3 \%$ of the total cost.

In Ontario, the total population-level costs for asthma in children aged 0-9 years ranged from $\sim \$ 140$ million during 1994-1995 to \$120 million in 1998-1999 [24].

\section{Patient-level indirect costs}

About $50 \%$ of children missed 1-3 days of school (47.6\% in the group with low-severity asthma, $53.9 \%$ in those with moderate severity, and $50.6 \%$ in the severe asthma group), and $5.7 \%$ of the low severity, $5.3 \%$ of the moderate severity, and $9.1 \%$ of the severe asthma patients were absent for 7 or more days [47].

Malo et al. [46] evaluated a random sample of 8 to 10 accepted claims for occupational asthma per year from 1988 to 2002 in Quebec and found that the mean cost of compensation for loss of income (CLI) across the 15 years (not accounting for inflation) was $\$ 72,500$ (median \$40,700) and the mean cost of compensation for functional impairment (CFI) was $\$ 11,700$ (median \$7,600). Median CLI costs were significantly higher in men than women (69.9 vs 13.1), in workers

Table 9 Summary of studies that reported population-level total direct costs for asthma

\begin{tabular}{lllll}
\hline Reference/Study period & Age group & Patient group & Total annual population cost & Inflated 2011 \$CAD \\
\hline Retrospective cohort studies & & & & \\
Sadatsafavi et al. 2010 [10] April 1996- March 2000 & $5-55$ yrs & Narrow asthma definition & $\$ 41,858,610$ & $\$ 46,285,583$ \\
& & Broad asthma definition & $\$ 56,114,574$ & $\$ 62,049,260$ \\
To et al. 2008 [24] 1994-1998 & 0-9 yrs & $1994 / 1995$ & $\$ 116,700,000$ & $\$ 140,882,165$ \\
& & $1995 / 1996$ & $\$ 114,800,000$ & $\$ 138,588,454$ \\
& & $1996 / 1997$ & $\$ 106,900,000$ & $\$ 129,051,443$ \\
& & $1997 / 1998$ & $\$ 105,300,000$ & $\$ 119,897$ \\
& $1998 / 1999$ & $\$ 98,900,000$ & &
\end{tabular}


aged $\geq 40$ years versus those $<40$ years ( 90.1 vs 27.4 ), and in workers taking inhaled steroids at diagnosis (92 vs 52) and at reassessment ( 81 vs 35 ). Median CFI costs were significantly higher for individuals being treated with inhaled steroids at the time of diagnosis (14.0 vs 5.2$)$ and reassessment (13 vs 6 ).

\section{Population-level indirect costs}

In a population of $\sim 1.5$ million working-age individuals in Alberta with an asthma prevalence of $8.5 \%$, the number of asthma-related productivity lost work days ranged from 441,728 to 533,363 in 1 year, at a cost of $\$ 78.1$ to $\$ 94.4$ million in lost productivity [48].

Ungar et al. [49] reported productivity loss days (PLD) without reporting actual indirect costs. They found that annual PLD varied from 12 in employed persons to 20 in students, 22 in homemakers, retirees and the unemployed, and 49 in disability pensioners. Annual PLDs increased with increasing disease severity.

\section{Humanistic burden studies \\ Overview}

Fourteen articles reporting results from 13 studies were retained for inclusion out of the 309 studies identified by the humanistic burden literature search. Two were cohort studies, 8 were cross-sectional, and 4 studies were RCTs. Only 1 of these was a pediatric study [50], which assessed the impact of asthma medication on children using the 3-domain Pediatric Asthma Quality of Life Questionnaire (PAQLQ). No studies were identified that reported utilities or QoL from a caregiver perspective. QoL assessments focused on subgroups of the asthma population, and studies had small numbers of participants. A variety of definitions were used to define asthma including clinical diagnosis, presence of symptoms, and positive inhalation tests. Characteristics of studies reporting on humanistic burden are detailed in Table 10.

Overall, most studies on humanistic burden met good reporting quality standards in accordance with STROBE criteria (Table 1). However, less than half of the studies reported how missing data and loss to follow-up was handled or sensitivity or other analyses performed. Most studies also met the STROBE criteria for appropriate quality discussion (80\%) and reported information on study funding (80\%).

The effect of psychiatric disorders on asthma control and QoL in adults was examined in 2 studies $[57,58]$. Another 2 studies examined QoL by asthma severity and chronicity [54,62]. Eleven studies used the 32-item AQLQ to assess the impact of asthma on patients' QoL [51-56,58-63]. Other tools that were used to measure the humanistic burden of asthma were the AQL-5D, the EQ-5D, the SF-6D, the Health Utilities Index (HUI-3), the Asthma Control Questionnaire (ACQ), and the 8question St Georges Respiratory Questionnaire (SGRQ).

\section{Key findings on humanistic burden}

Depression and anxiety were prevalent among asthma patients and were associated with worse asthma control and quality of life (QoL) [52]. Yacoub et al. reported a 50\% prevalence of anxiety and/or depression among 40 subjects with occupational asthma [56]. In a study conducted by Lavoie et al., 31\% of 504 adults with physician-diagnosed asthma met the diagnostic criteria for 1 or more psychiatric diagnoses [57]. A study specifically looking at occupational asthma also found that psychological distress and psychiatric disorders including depression, anxiety, and dysthymia were associated with impaired QoL [63].

As one would expect, QoL became progressively worse as disease severity increased [54,62]. Furthermore, QoL was lower in asthma patients who had at least 1 other chronic disease compared to those who had no other chronic disease [54].

A study of 504 consecutive adults with physiciandiagnosed asthma reported that depressive and anxiety disorders were both independently associated with decreased health-related QoL (as measured by AQLQ scores), but only depressive disorders were independently associated with worse asthma control (as measured by ACQ scores) [57]. Interestingly, having both depressive and anxiety disorders did not increase the risk for worse asthma control or decreased QoL [57]. According to the study authors, this finding suggests that there is no incremental risk associated with having both a depressive disorder and an anxiety disorder on asthma control and QoL. The researchers also noted that the lack of an independent association between anxiety disorders and asthma control may be due to the fact that patients with anxiety disorder are more inclined to selfmonitor their symptoms, and are thus more likely than depressed patients to detect asthma symptoms and seek intervention.

Lavoie et al. [58] studied the association between clinical measures of asthma morbidity and body mass index (BMI), and found that patients with higher BMI scores had worse asthma control and poorer QoL (i.e., higher ACQ and lower AQLQ scores), independent of age, gender, and asthma severity. However, BMI was not associated with asthma severity.

\section{Discussion}

This review is the first to summarize the literature encompassing not only the clinical and economic burden of asthma, but also the humanistic burden of asthma in Canada. This systematic review confirms that the burden associated with asthma is substantial, and will undoubtedly become more pronounced as the 


\begin{tabular}{|c|c|c|c|c|}
\hline Reference/Study period & Design & Study objective & Inclusion criteria & Asthma definition \\
\hline $\begin{array}{l}\text { Miedinger et al. } \\
2011[51] \\
2004-2006\end{array}$ & $\begin{array}{l}\text { Longitudinal study- } \\
\text { subjects who } \\
\text { claimed compensa- } \\
\text { tion for OA in } \\
\text { Quebec }\end{array}$ & $\begin{array}{l}\text { Examine association between clinical and } \\
\text { socioeconomic variables and psychological } \\
\text { and cost outcomes in patients with OA }\end{array}$ & $\begin{array}{l}\text { Claimed compensation for OA at CSST, not } \\
\text { exposed to offending allergens causing OA } \\
\text { for } \geq 2 \text { years }\end{array}$ & $\begin{array}{l}\text { Workplace-associated respiratory symptoms } \\
\text { and positive results in specific inhalation test }\end{array}$ \\
\hline $\begin{array}{l}\text { Lavoie et al. } 2010 \\
\text { [52] NR }\end{array}$ & $\begin{array}{l}\text { Prospective cohort, } \\
\text { self-report } \\
\text { questionnaires }\end{array}$ & $\begin{array}{l}\text { Assess level of psychological distress and } \\
\text { range of disease-relevant emotional and be- } \\
\text { havioural coping styles in patients with se- } \\
\text { vere vs. moderate asthma }\end{array}$ & $\begin{array}{l}\text { Patients aged } 18-69 \text { years recruited from } 2 \\
\text { tertiary care outpatient asthma clinics }\end{array}$ & $\begin{array}{l}\text { Standard ATS criteria; Severe asthma - re- } \\
\text { ceived adequate therapy and verified treat- } \\
\text { ment adherence, with patients meeting ATS } \\
\text { major and minor criteria for severe asthma }\end{array}$ \\
\hline $\begin{array}{l}\text { Bacon et al. } \\
2009[53] \\
\text { Jun } 2003- \\
\text { Jan } 2007\end{array}$ & $\begin{array}{l}\text { Cross-sectional study; } \\
\text { patients } \\
\text { administered } \\
\text { questionnaires }\end{array}$ & $\begin{array}{l}\text { Assess associations between adult SES } \\
\text { (measured according to educational level) } \\
\text { and asthma morbidity, including asthma } \\
\text { control; asthma-related emergency health } \\
\text { service use; asthma self-efficacy, and asthma- } \\
\text { related QoL }\end{array}$ & $\begin{array}{l}\text { Patients aged } 18-75 \text { years, recruited from } \\
\text { outpatient asthma clinic of Hôpital du Sacré- } \\
\text { Coeur de Montréal }\end{array}$ & $\begin{array}{l}\text { Physician-diagnosed asthma - charted } 20 \% \\
\text { fall in FEV1 after methacholine challenge } \\
\text { and/or bronchodilator reversibility in FEV1 of } \\
\geq 20 \% \text { predicted; severity based on GINA } \\
\text { guidelines (mild intermittent, mild persistent, } \\
\text { moderate persistent, and severe persistent) }\end{array}$ \\
\hline
\end{tabular}
NR

Rowe et al. 2007

[55] NR

Yacoub et al. 2007 [56] 2004 2006

Lavoie et al.

$2006[57]$

$2003-2005$

Lavoie et al. 2006 [58]

Jun 2003 to

Apr 2004

Lavoie et al. 2005

[52] NR

Mo et al. 2004 [59] 2000 - 2001 $\begin{array}{ll}\text { Cross-sectional - self- } & \text { Evaluate validity of HUI-3, EQ-5D, SF-6D, an } \\ \text { administered } & \text { AQL-5D to distinguish between different }\end{array}$ questionnaire levels of asthma control

RCT (double-blind) Examine effect of adding a LABA (salmetero) -structured tele- $\quad$ to fixed dose of oral prednisone and ICS phone interviews (fluticasone) Retrospective cohort Evaluate utility of adding assessment of study; questionnaire administered to subjects airway inflammation to standard assessment of impairment in subjects with $O A$; to evaluate psychological and QoL impact of $\mathrm{OA}$

Cross-sectional study; Evaluate relative impact of having a structured psychiatric depressive and/or anxiety disorder on interview asthma control and QoL

Cross-sectional study; Assess BMI in a Canadian sample of asthma patients completed outpatients, and evaluate associations ACQ and AQLQ between BMI and levels of asthma severity, questionnaires asthma control, and asthma-related QoL

Cross-sectional study; Evaluate prevalence of psychiatric disorders patients completed in adult asthma patients and associations $A C Q$ and $A Q L Q$ between psychiatric status, levels of asthma questionnaires control, and asthma-related QoL

Patients aged 19-49 years,no other concurrent respiratory condition

Patients aged $18-55$ years, PEF of $<80 \%$ predicted before treatment, discharged from ED

Workers' Compensation Agency of Quebec claimants

Patients aged 18-75 years with primary diagnosis of asthma

Patients aged 18-75 years with primary diagnosis of asthma, fluency in either English or French

Patients aged 18-75 years with primary diagnosis of asthma, fluency in either English or French

Self-reported, physician-diagnosed asthma

Clinically diagnosed acute asthma in ED; PEF of $<80 \%$ predicted before treatment

OA claimants

Physician-diagnosed asthma - chart evidence of 20\% fall in FEV1 after methacholine challenge and/or bronchodilator reversibility in FEV1 20\% predicted; severity classified according to international GINA guidelines

Physician diagnosed asthma - chart evidence of $20 \%$ fall in FEV1 after methacholine challenge and/or bronchodilator reversibility in FEV1 20\% predicted; severity classified according to GINA guidelines

Physician diagnosed asthma - confirmed by chart evidence of $20 \%$ fall in FEV1 after methacholine challenge and/or bronchodilator reversibility in FEV1 20\% predicted; severity classified according to GINA guidelines

Cross-sectional study; Measure HRQL of chronic disease and detect All household residents aged $\geq 12$ years in all NR HUI used to measure associations between HUI system and provinces and territories 


\section{Table 10 Characteristics of humanistic burden studies included in the review (Continued)}

\begin{tabular}{|c|c|c|c|c|}
\hline $\begin{array}{l}\text { FitzGerald et al. } \\
2000[60]\end{array}$ & $\begin{array}{l}\text { RCT - AQLQ adminis- } \\
\text { tered to assess QoL }\end{array}$ & $\begin{array}{l}\text { Compare effectiveness of prednisone and } \\
\text { budesonide on relapse rate }\end{array}$ & $\begin{array}{l}\text { Patients aged } 15-70 \text { years, recruited after } \\
\text { discharge from ED after acute asthma } \\
\text { exacerbation }\end{array}$ & $\begin{array}{l}\text { Asthma exacerbation - progressive increase } \\
\text { in dyspnea and history of asthma as per ATS } \\
\text { criteria }\end{array}$ \\
\hline $\begin{array}{l}\text { Williams et al. } 2010 \text { [61] Baseline to } \\
\text { week } 12\end{array}$ & $\begin{array}{l}\text { RCT AQLQ data from } \\
\text { first } 12 \text { weeks of the } \\
\text { GOAL study }\end{array}$ & $\begin{array}{l}\text { Compare AQLQ data across } 16 \text { countries ( } 17 \\
\text { languages) }\end{array}$ & $\begin{array}{l}\text { Patients aged } 12 \text { to }<80 \text { years with } \geq 6 \text { - } \\
\text { month history of asthma }\end{array}$ & NR \\
\hline $\begin{array}{l}\text { Miedinger et al. } \\
2011[51] \\
2004 \text { to } 2006\end{array}$ & $\begin{array}{l}\text { Cross-sectional study; } \\
\text { participants } \\
\text { completed validated } \\
\text { French versions of } \\
\text { QoL questionnaires }\end{array}$ & $\begin{array}{l}\text { Assess correlation between asthma-specific } \\
\text { QoL and levels of psychological distress and } \\
\text { psychiatric disorders in patients with OA }\end{array}$ & $\begin{array}{l}\text { Patients who claimed compensation for OA } \\
\text { at CSST; no longer exposed to sensitizing } \\
\text { agents } \geq 2 \text { years }\end{array}$ & $\begin{array}{l}\text { OA - asthma caused and maintained by con- } \\
\text { ditions attributable to the occupational en- } \\
\text { vironment and not to stimuli encountered } \\
\text { outside the workplace }\end{array}$ \\
\hline $\begin{array}{l}\text { Zimmerman et al. } \\
\text { 2004 [50] } \\
\text { 12-week study }\end{array}$ & $\begin{array}{l}\text { RCT (double-blind); } \\
\text { patients } \\
\text { administered PAQLQ }\end{array}$ & $\begin{array}{l}\text { Examine efficacy and safety of adding } \\
\text { regular formoterol at } 2 \text { different doses to } \\
\text { maintenance treatment with ICS in children } \\
\text { with asthma not optimally treated by ICS } \\
\text { alone }\end{array}$ & $\begin{array}{l}\text { Patients aged } 6-11 \text { years with clinical } \\
\text { diagnosis of asthma as per ATS criteria for } \\
\geq 6 \text { months; FEV1 } 50-90 \% \text { of predicted nor- } \\
\text { mal; documented post-bronchodilator revers- } \\
\text { ibility of } \geq 15 \%, \geq 9 \% \text { of predicted normal; } \\
\text { treatment with regular ICS for } \geq 3 \text { months } \\
\text { before trial entry; asthma symptoms suffi- } \\
\text { cient to suggest additional therapy may be } \\
\text { needed; ability to use peak flow meter and } \\
\text { Turbuhaler, able to answer questions from } \\
\text { PAQLQ; parent/guardian to complete daily } \\
\text { diary }\end{array}$ & $\begin{array}{l}\text { Clinical diagnosis of asthma defined } \\
\text { according to ATS criteria; severe asthma } \\
\text { exacerbation defined as asthma symptoms } \\
\text { requiring oral corticosteroids or increase in } \\
\text { dose of ICS as judged by the investigator }\end{array}$ \\
\hline
\end{tabular}

ACQ=Asthma Control Questionnaire; AQLQ=Asthma Quality of Life Questionnaire; AQL-5D=Asthma Quality of Life-5D ; ATS=American Thoracic Society; BMI=body mass index; BUD=budesonide; CSST=Commission de la Santé et de la Sécurité du Travail du Québec (Canadian Centre for Occupational Health and Safety); ED=emergency department; EQ-5D =EuroQoL 5-D ; FEV1=forced expiration volume in 1 second; GINA=Global Initiative for Asthma; GOAL=Gaining Optimal Asthma ControL (study); GSCs=glucocorticosteroid; HRQoL = health-related quality of life; HUI=health utilities index; ICS=inhaled corticosteroid; LABA=long-acting $\beta$-agonist; NR=not reported; $\mathrm{OA}=$ occupational asthma; PAQLQ=Pediatric Asthma Quality of Life Questionnaire; PEF=peak expiratory flow; PRED=prednisone; PRIME-MD=Primary Care Evaluation of Mental Disorders; $\mathrm{PSI}=$ Psychiatric Symptom Index; $\mathrm{QoL}=$ quality of life; $\mathrm{RCT}=$ randomised controlled trial; $S E S=$ socioeconomic status; SF-6D=Short-Form $6 \mathrm{D} ; \mathrm{SGRQ}=\mathrm{St}-\mathrm{Georges}$ Respiratory Questionnaire. 
asthma prevalence increases in Canada. The asthma burden as it is known today can likely be decreased by the development and implementation of innovative treatment strategies in the management of this disease.

A considerable body of literature was included in this systematic review (33 articles for the clinical and economic burden and 14 for the humanistic burden).The reviewed literature suggested that the healthcare resource utilization in asthma varied greatly in Canada by age group and type of treatment used. The substantial clinical burden was reflected by high rates of hospitalizations, ED and physician visits, and medication use. Lower rates of ED visits and hospitalizations, as well as reduced deaths, were observed among ICS users compared with non-users (except among the elderly), but these reductions were not as pronounced in patients who had experienced recent asthma exacerbations.

We collected evidence on both the direct and indirect components of the economic burden of asthma in Canada. The overall burden varied based on whether studies reported costs from the perspective of an individual patient with asthma or costs at the population level. Reported estimates for patient-level total direct costs, inflated to 2011 Canadian dollars, ranged from $\$ 99.33$ per patient in a cohort of children aged 0-14 years in Ontario (May - October 1995) [33] to $\$ 646.95$ per patient in a cohort of children aged 0-9 years, also in Ontario (1994/1995) [24]. Reported estimates for population-level total direct costs, inflated to 2011 Canadian dollars, ranged from $\$ 46,285,583$ for patients aged 5-55 years in British Columbia (April 1996 - March 2000) [10] to $\$ 140,882,165$ for patients aged 0-9 years in Ontario (1994-1998) [24]. Few Canadian studies reported a cost per episode of acute asthma.

Fourteen studies assessed the impact of asthma on the QoL of patients; however, only 4 reported on QoL of children with asthma, which represents a significant knowledge gap. For the most part, QoL assessments focused on subgroups of the asthma population and studies had small numbers of participants. Asthma was associated with depression and/or anxiety in several studies.

As noted above, these research studies vary considerably in terms of geographic region of study, characteristics of patient populations, study methodologies, and definitions of asthma used, which presents a significant challenge in drawing definitive conclusions from our study. Furthermore, unique findings reported in single studies have yet to be confirmed or refuted by subsequent research. Thus, in our review, results are presented as reported, but no consensus can be reached on the rates of resource utilization among asthmatic patients, asthma-related costs, or the degree of QoL impairment among individuals with asthma. Our study suggests that there is a significant knowledge gap in understanding the comprehensive burden of asthma across Canada.
Nevertheless, the high rates of healthcare resource utilization observed among patients with asthma during this review revealed only the tip of the iceberg. The economic burden is noteworthy, with direct costs - particularly those related to hospitalizations and physician/ED visits - representing the highest proportion of asthmarelated costs. The indirect costs mainly due to time loss from work, productivity loss, functional impairment and caregiver time also add to this significant burden. Although there is a paucity of research on the humanistic burden of asthma in Canada, the few studies included in this review indicate that QoL is unquestionably diminished in asthmatic patients and that there is a high prevalence of psychological distress and psychiatric disorders among patients with asthma. Notable knowledge gaps on the humanistic burden of asthma are the lack of QoL assessments in children and caregivers, as well as quantifying the asthma-attributable burden in this patient population.

This systematic review provides a holistic overview of the burden of asthma in Canada, detailing the direct and indirect costs, the key drivers of healthcare resource utilization, and the impact of asthma on patients' quality of life - information that cannot be inferred from clinical measures. This information can be of value to payers, policy makers and healthcare providers in making decisions pertaining to the management and treatment of asthma.

For example, knowing that depression is often associated with asthma and that its severity and asthma control are intertwined, it might be useful to have psychologists/psychiatric healthcare professionals on the disease management team from the time of asthma diagnosis. Also, findings that BMI levels and asthma control and QoL are related, can lead to adding interventional measures to the treatment strategy.

As far as treatment options go, the use of inhaled corticosteroids was noted in many of the reviewed articles to be associated with lower rates of ED visits and hospitalizations; therefore recommending the appropriate use of medications (low-dose SABA plus high-dose ICS) should be emphasized.

More research in Canada is needed to add to the holistic picture of the impact of this disorder on the lives of patients, their families, and caregivers. Furthermore, much remains to be learned about the optimal use of the currently available treatments, how to combine them for maximal benefit, and how to incorporate new drugs in development into existing treatment regimens.

\section{Limitations}

All literature reviews are limited by the publication bias of the articles that are available. We acknowledge the fact that studies identifying a significant burden of asthma 


\section{Table 11 Clinical and economic burden search strategy}

\section{Medline (1996 to present)}

1 Asthma[MeSH] OR Asthma [Title,abstract]

2 hospitalisation[MeSH] OR cost of illness[MeSH] OR absenteeism OR ambulatory care/Economics[MeSH] OR drug costs[MeSH] OR emergency medical services/Economics[EMTREE] OR healthcare costs[MeSH] OR nursing services/Economics[MeSH] OR physicians/ Economics[MeSH]

3 (burden OR clinical impact OR hospitalisation OR utilization OR burden of illness OR cost\$1 OR cost of illness OR utilization OR nursing cost\$1 OR physician cost\$1 OR physician visit\$1).TI,AB.

41 AND (2 OR 3)

5 canada OR canadian OR alberta OR british columbia OR manitoba OR new brunswick OR newfoundland NEXT labrador OR territory

64 AND 5 AND LG=English AND HUMAN=YES

7 Publication Type=RANDOMIZED CONTROLLED TRIAL

86 NOT 7

9 limit set 8 YEAR > 1999

EmBase (1992 to present)

10 Asthma[EMTREE] OR Asthma[Title,abstract]

11 hospitalisation[EMTREE] OR cost of illness[EMTREE] OR cost[EMTREE] OR absenteeism[EMTREE] OR drug cost[EMTREE] OR healthcare cost[EMTREE] OR nursing cost[EMTREE]

12 (burden OR clinical impact OR hospitalisation OR utilization OR burden of illness OR cost\$1 OR cost of illness OR utilization OR nursing cost\$1 OR physician cost\$1 OR physician visit\$1)[Title,abstract]

1310 AND (11 OR 12)

14 canada OR canadian OR alberta OR british columbia OR manitoba OR new brunswick OR newfoundland NEXT labrador OR northwest territories OR nova scotia OR nunavut OR ontario OR prince edward island OR quebec OR saskatchewan OR yukon NEXT territory

1513 AND 14 AND LG=English AND HUMAN=YES

16 Randomized Controlled Trial[EMTREE] OR Randomized Controlled Trial Topic[EMTREE]

1715 NOT 16

18 limit set 17 YEAR $>1999$

EMCare

19 Asthma[EMTREE] OR Asthma[Title,abstract]

20 hospitalisation[EMTREE] OR cost of illness[EMTREE] OR cost[EMTREE] OR absenteeism[EMTREE] OR drug cost[EMTREE] OR healthcare cost[EMTREE] OR nursing cost[EMTREE]

21 (burden OR clinical impact OR hospitalisation OR utilization OR burden of illness OR cost\$1 OR cost of illness OR utilization OR nursing cost\$1 OR physician cost\$1 ORphysician visit\$1)[Title,abstract]

2219 AND (20 OR 21)

23 canada OR canadian OR alberta OR british columbia OR manitoba OR new brunswick OR newfoundland NEXT labrador OR northwest territories OR nova scotia OR nunavut OR ontario OR prince edward island OR quebec OR saskatchewan OR yukon NEXT territory

2422 AND 23 AND LG=EN

25 Randomized Controlled Trial[EMTREE] OR Randomized Controlled Trial[EMTREE]

27 limit set 26 YEAR > 1999

\section{Medline, EmBase and EMCare combined}

28 combined sets $9,18,27$

29 dropped duplicates from 28

486

30 unique records from 28

575

31 split set 30

320 Medline

32 split set 30

234 EmBase 
Table 12 Humanistic burden search strategy

\begin{tabular}{|c|c|c|}
\hline \multicolumn{3}{|c|}{ Medline } \\
\hline 1 & Asthma[MeSH] OR Asthma[Title,Abstract] & 71642 \\
\hline 2 & Sickness impact profile[MeSH] OR quality of life[MeSH] OR patient satisfaction[MeSH] & 121478 \\
\hline 3 & $\begin{array}{l}\text { (quality of life OR QoL OR patient reported outcome\$1 OR patient satisfaction OR emotional satisfaction OR patient dissatisfaction } \\
\text { OR patient response OR gratification OR treatment satisfaction OR disability rate\$1 OR health related quality of life OR HRQOL OR } \\
\text { utilities) [Title,Abstract] }\end{array}$ & 119368 \\
\hline 4 & 1 AND (2 OR 3) & 3035 \\
\hline 5 & $\begin{array}{l}\text { canada OR canadian OR alberta OR british columbia OR manitoba OR new brunswick OR newfoundland NEXTlabrador OR northwest } \\
\text { territories OR nova scotia OR nunavut OR ontario OR prince edward island OR quebec OR saskatchewan OR yukon NEXT territory }\end{array}$ & 462814 \\
\hline 6 & 4 AND 5 AND LG=English AND HUMAN=YES & 172 \\
\hline 7 & limit set 6 YEAR > 1999 & 141 \\
\hline \multicolumn{3}{|c|}{ EmBase } \\
\hline 8 & Asthma[EMTREE] OR Asthma[Title,Abstract] & 100645 \\
\hline 9 & Sickness impact profile[EMTREE] OR quality of life[EMTREE] OR patient satisfaction[EMTREE] & 199618 \\
\hline 10 & $\begin{array}{l}\text { (quality of life OR QOL OR patient reported outcome\$1 OR patient satisfaction OR emotional satisfaction OR patient dissatisfaction } \\
\text { OR patient response OR gratification OR treatment satisfaction OR disability rate\$1 OR health related quality of life OR HRQoL OR } \\
\text { utilities) [Title,Abstract] }\end{array}$ & 124979 \\
\hline 11 & 8 AND (9 OR 10) & 5651 \\
\hline 12 & $\begin{array}{l}\text { canada OR canadian OR alberta OR british columbia OR manitoba OR new brunswick OR newfoundland NEXT labrador OR } \\
\text { northwest territories OR nova scotia OR nunavut OR Ontario OR prince edward island OR quebec OR saskatchewan OR yukon NEXT } \\
\text { territory }\end{array}$ & 462680 \\
\hline 13 & 11 AND 12 AND LG=English AND HUMAN=YES & 306 \\
\hline 14 & limit set 13 YEAR > 1999 & 267 \\
\hline \multicolumn{3}{|c|}{ EMCare } \\
\hline 15 & Asthma[EMTREE] OR Asthma[Title,Abstract] & 28554 \\
\hline 16 & Sickness impact profile[EMTREE] OR quality of life[EMTREE] OR patient satisfaction[EMTREE] & 94595 \\
\hline 17 & $\begin{array}{l}\text { (quality of life OR QoL OR patient reported outcome\$1 OR patient satisfaction OR emotional satisfaction OR patient dissatisfaction } \\
\text { OR patient response OR gratification OR treatment satisfaction OR disability rate\$1 OR health related quality of life OR HRQOL OR } \\
\text { utilities) [Title,Abstract] }\end{array}$ & 48206 \\
\hline 18 & 15 AND (16 OR 17) & 2178 \\
\hline 19 & $\begin{array}{l}\text { canada OR canadian OR alberta OR british columbia OR manitoba OR new brunswick OR newfoundland NEXT labrador OR } \\
\text { northwest territories OR nova scotia OR nunavut OR Ontario OR prince edward island OR quebec OR saskatchewan OR yukon NEXT } \\
\text { territory }\end{array}$ & 174145 \\
\hline 20 & 18 AND 19 AND LG=English & 137 \\
\hline 21 & limit set 20 YEAR > 1999 & 111 \\
\hline \multicolumn{3}{|c|}{ Medline, EmBase and EMCare combined } \\
\hline 22 & combined sets $7,14,21$ & 519 \\
\hline 23 & dropped duplicates from 22 & 207 \\
\hline 24 & unique records from 22 & 312 \\
\hline 25 & split set 24 & $\begin{array}{l}141 \\
\text { Medline }\end{array}$ \\
\hline 26 & split set 24 & $\begin{array}{l}158 \\
\text { EmBase }\end{array}$ \\
\hline 27 & split set 24 & 13 EMCare \\
\hline
\end{tabular}

may likely be published than the ones reporting a low burden. The articles in this review are limited to the English language, and publication constraints were placed on articles identified by the search with studies limited to those published since 2000. Spatial restrictions were also applied, limiting studies to Canada. Studies employed a variety of defining criteria for asthma (from patient selfreport to ICD-codes, from physician-recorded diagnosis to discharge diagnosis combined with medication use), and these definitions were not reconciled in this review. This may have led to underreporting or overreporting of certain outcomes. Results were analyzed as reported, but 
direct comparisons between studies are lacking, due to the high heterogeneity of methodological approaches.

In spite of these limitations, this review was systematic in nature and summarizes all available and relevant data published since 2000 , thus providing a better understanding of the literature with respect to the clinical, economic, and humanistic burden of asthma.

\section{Conclusions}

The information contained within this study provides a comprehensive overview of the burden of asthma in Canada. Moreover, our study identifies several key knowledge gaps in understanding this area. As new therapies for asthma become available, health technology assessments will become increasingly important not only as it pertain to amendments to clinical practice guidelines but also with regard to formulating reimbursement decisions. Our study summarizes information that can prove important for physicians, healthcare authorities, and government officials involved in the treatment selection and development of disease management guidelines for asthma.

\section{Appendix}

The Appendix tables present the literature search strategies used to retrieve articles reporting on the clinical and economic burden (Table 11) and humanistic burden (Table 12) of asthma. The strategies were applied to the Medline. EmBase and EMCare databases.

\section{Competing interests}

ASI and APS are employees in the Medical Division of GlaxoSmithKline Inc., Canada. ASI is also an assistant professor (part-time) in the Department of Clinical Epidemiology and Biostatistics at McMaster University, Hamilton, Ontario, Canada. MM is an employee of Optum. ZS was an employee of GSK at the time of the research and analyses of this project. ZS is currently an employee of Sanofi.

\section{Authors' contributions}

All authors contributed to the design and protocol of the study. ASI, MM and APS identified and reviewed the literature to include in the systematic review. ZS provided the medical interpretation of the data. APS coordinated the review and finalization of the manuscript. All authors reviewed the results of the analyses and contributed to, read and approved the final manuscript.

\section{Acknowledgments}

The authors thank Victoria Porter, medical writer at Optum, for her assistance with the preparation of this manuscript. Financial support for this study was provided by GlaxoSmithKline Inc. Canada.

\section{Author details}

${ }^{1}$ Medical Affairs, GlaxoSmithKline Canada, Mississauga, ON, Canada. ²Department of Clinical Epidemiology and Biostatistics, McMaster University, Hamilton, Ontario, Canada. ${ }^{3}$ Product Value Strategy Consulting, Optum, Burlington, Ontario, Canada. ${ }^{4}$ Medical Affairs, Sanofi, Cambridge, MA, USA.

Received: 27 March 2013 Accepted: 28 November 2013

Published: 5 December 2013

\section{References}

1. Masoli M, Fabian D, Holt S, Beasley R: Global initiative for asthma (GINA) program. Allergy 2004, 59:469-78.

2. Gershon A, Wang C, Cicutto L, To T: The burden of asthma: Can it be eased? Healthc Q 2007, 10:22-4.

3. Asthma Society of Canada: Asthma facts and statistics; 2012. Available at http://www.asthma.ca/corp/newsroom/pdf/asthmastats.pdf Last accessed August 27.

4. Lougheed MD, Lemiere C, Ducharme FM, Licskai C, Dell SD, Rowe BH, Fitzgerald M, Leigh R, Watson W, Boulet LP: Canadian thoracic society asthma clinical assembly: Canadian thoracic society 2012 guideline update: diagnosis and management of asthma in preschoolers, children and adults. Can Respir J 2012, 19:127-164.

5. Statistics Canada: asthma; 2010. website [http://www.statcan.gc.ca/pub/82625-x/2011001/article/11458-eng.htm ]

6. To T, Gershon A, Cicutto L, Wang CN: The burden of asthma: can it be eased? The Ontario record. Healthc Q 2007, 10:22-4.

7. Statistics Canada, Millar WJ, Gerry BH: Childhood asthma. Health Rep 1998, 10:12. http://www5.statcan.gc.ca/bsolc/olc-cel/olc-cel?catno=82-003x19980034137\&lang=eng.pdf

8. Statistics Canada, Garner R, Kohen D: Changes in the prevalence of childhood asthma. Health Rep 2008. catalogue 82-003-X. http://www.statcan.gc.ca/pub/82-003-x/2008002/article/10551-eng.pdf.

9. Bahadori K, Doyle-Waters MM, Marra C, Lynd L, Alasaly K, Swiston J, FitzGerald JM: Economic burden of asthma: a systematic review. BMC Pulm Med 2009, 9:24

10. Sadatsafavi M, Lynd L, Marra C, Carleton B, Tan WC, Sullivan S, Fitzgerald JM: Direct health care costs associated with asthma in British Columbia. Can Respir J 2010, 17:74-80.

11. Bousquet J, Bousquet PJ, Godard P, Daures JP: The public health implications of asthma. Bull World Health Organ 2005, 83:548-54

12. Braman SS: The global burden of asthma. Chest 2006, 130:4S-12S.

13. Juniper EF: Using humanistic health outcomes data in asthma. Pharmacoecon 2001, 19(Suppl 2):13-9.

14. National Institute for Health and Clinical Excellence: The guidelines manual (January 2009). London: National Institute for Health and Clinical Excellence; 2011. Available at www.nice.org.uk.

15. STROBE Statement (2009). 2012. Available at http://www.strobe-statement org/index.php?id=available-checklists.

16. Vandenbroucke JP, von Elm E, Altman DG, Gøtzsche PC, Mulrow CD, Pocock SJ, Poole C, Schlesselman JJ, Egger M: STROBE initiative: strengthening the reporting of observational studies in epidemiology (STROBE): explanation and elaboration. PLoS Med 2007, 4:e297.

17. Statistics Canada: Consumer price index. 2012. Available at http://www. statcan.gc.ca.

18. Blais $L$, Beauchesne $M-F$, Forget $A$ : Acute care among asthma patients using budesonide/formoterol or fluticasone propionate/salmeterol. Respir Med 2009, 103:237-43.

19. Rosychuk R, Voaklander D, Klassen T, Senthilselvan A, Marrie TJ, Rowe BH: Asthma presentations by children to emergency departments in a Canadian province: a population-based study. Pediatr Pulmonol 2010, 45:985-92.

20. Crighton EJ, Mamdani MM, Upshur RE: A population based time series analysis of asthma hospitalisations in Ontario, Canada: 1988 to 2000. BMC Health Serv Res 2001, 1:7.

21. Ungar W, Paterson J, Gomes T, Bikangaga P, Gold M, To T, Kozyrskyj AL: Relationship of asthma management, socioeconomic status, and medication insurance characteristics to exacerbation frequency in children with asthma. Ann Allergy Asthma Immunol 2011, 106:17-23.

22. Disano J, Goulet J, Muhajarine N, Neudorf C, Harvey J: Social-economic status and rates of hospital admission for chronic disease in urban Canada. Can Nurse 2010, 106:24-9.

23. Rowe BH, Bota GW, Clark S, Camargo CA: Multicenter airway research collaboration investigators. Comparison of Canadian vs. American emergency department visits for acute asthma. Can Respir J 2007, 14:331-7.

24. To T, Dell S, Dick P, Cicutto L: The burden of illness experienced by young children associated with asthma: a population-based cohort study. J Asthma 2008, 45:45-9.

25. Lemiere C, Forget A, Dufour M, Boulet LP, Blais L: Characteristics and medical resource use of asthmatic subjects with and without workrelated asthma. J Allergy Clin Immunol 2007, 120:1354-9. 
26. To T, Gershon A, Wang C, Dell S, Cicutto L: Persistence and remission in childhood asthma: a population-based asthma birth cohort study. Arch Pediatr Adolesc Med 2007, 161:1197-204.

27. Agha M, Glazier R, Guttmann A: Relationship between social inequalities and ambulatory care-sensitive hospitalisations persists for up to 9 years among children born in a major Canadian urban center. Ambul Pediatr 2007, 7:258-62.

28. Lougheed M, Garvey N, Chapman K, Cicutto L, Dales R, Day AG, Hopman WM, Lam M, Sears MR, Szpiro K, To T, Paterson NA: Ontario respiratory outcomes research network: the Ontario asthma regional variation study: emergency department visit rates and the relation to hospitalization rates. Chest 2006, 129:909-17.

29. Dik N, Anthonisen N, Manfreda J, Roos LL: Physician-diagnosed asthma and allergic rhinitis in Manitoba: 1985-1998. Ann Allergy Asthma Immunol 2006, 96:69-75.

30. Sin DD, Tu JV: Inhaled corticosteroid therapy reduces the risk of rehospitalisation and all-cause mortality in elderly asthmatics. Eur Respir J 2001, 17:380-5.

31. Rowe BH, Villa Roel C, Abu-Laban RB, Stenstrom R, Mackey D, Stiell IG, Campbell S, Young B: Admissions to Canadian hospitals for acute asthma: a prospective, multicenter study. Can Respir J 2010, 17:25-30.

32. Sin D, Svenson L, Cowie RL, Man SF: Can universal access to healthcare eliminate health inequities between children of poor and nonpoor families?: A case study of childhood asthma in Alberta. Chest 2003, 124:51-6.

33. Ungar WJ, Coyte PC: Pharmacy medication monitoring program advisory board. Prospective study of the patient-level cost of asthma care in children. Pediatr Pulmonol 2001, 32:101-8.

34. Anis AH, Guh D, Stieb D, Leon H, Beveridge RC, Burnett RT, Dales RE: The costs of cardiorespiratory disease episodes in a study of emergency department use. Can J Public Health 2000, 91:103-6.

35. Boulet L, FitzGerald J, Mclvor R, Zimmerman S, Chapman KR: Influence of current or former smoking on asthma management and control. Can Respir J 2008, 15:275-9.

36. Klomp H, Lawson J, Cockcroft D, Chan BT, Cascagnette P, Gander L, Jorgenson D: Examining asthma quality of care using a population-based approach. CMAJ 2008, 178:1013-21.

37. Iron $K$, Manuel D, Williams J: Using a linked data set to determine the factors associated with utilization and costs of family physician services in Ontario: effects of self-reported chronic conditions. Chronic Dis Can 2003, 24:124-32

38. Anis AH, Lynd LD, Wang XH, King G, Spinelli JJ, Fitzgerald M, Bai T, Paré P: Double trouble: impact of inappropriate use of asthma medication on the use of healthcare resources. CMAJ 2001, 164:625-31.

39. Baibergenova A, Thabane L, Akhtar-Danesh N, Levine M, Gafni A, Moineddin $R$, Pulcins I: Effect of gender, age, and severity of asthma attack on patterns of emergency department visits due to asthma by month and day of the week. Eur J Epidemiol 2005, 20:947-56.

40. Lynd LD, Sandford AJ, Kelly EM, Paré PD, Bai TR, Fitzgerald JM, Anis AH: Reconcilable differences: a cross-sectional study of the relationship between socioeconomic status and the magnitude of short-acting beta-agonist use in asthma. Chest 2004, 126:1161-8.

41. Suissa S, Ernst P, Kezouh A: Regular use of inhaled corticosteroids and the long term prevention of hospitalisation for asthma. Thorax 2002, 57:880-4.

42. Seung S, Mittmann N: Urgent care costs of uncontrolled asthma in Canada, 2004. Can Respir J 2005, 12:435-6.

43. Blais L, Kettani F-Z, Lemière C, Beauchesne MF, Perreault S, Elftouh N, Ducharme FM: Inhaled corticosteroids vs. leukotriene-receptor antagonists and asthma exacerbations in children. Respir Med 2011, 105:846-55.

44. Sin DD, Tu JV: Underuse of inhaled steroid therapy in elderly patients with asthma. Chest 2001, 119:720-5.

45. Rowe B, Voaklander D, Wang D, Senthilselvan A, Klassen TP, Marrie TJ, Rosychuk RJ: Asthma presentations by adults to emergency departments in Alberta, Canada: a large population-based study. Chest 2009, 135:57-65.

46. Malo J, L'Archevêque J, Ghezzo H: Direct costs of occupational asthma in Quebec between 1988 and 2002. Can Respir J 2008, 15:413-6.

47. Kohen D: Asthma and school functioning. Health Rep 2010, 21:35-45.

48. Thanh NX, Ohinmaa A, Yan C: Asthma-related productivity losses in Alberta, Canada. J Asthma Allergy 2009, 2:43-8.

49. Ungar WJ, Coyte PC: Measuring productivity loss days in asthma patients the pharmacy medication monitoring program and advisory board. Health Econ 2000, 9:37-46.
50. Zimmerman B, D'Urzo A, Bérubé D: Efficacy and safety of formoterol turbuhaler ${ }^{\oplus}$ when added to inhaled corticosteroid treatment in children with asthma. Pediatr Pulmonol 2004, 37:122-7.

51. Miedinger D, Lavoie KL, L'Archeveque J, Ghezzo H, Malo JL: Identification of clinically significant psychological distress and psychiatric morbidity by examining quality of life in subjects with occupational asthma. Health Qual Life Outcomes 2011, 9:76.

52. Lavoie K, Cartier A, Labrecque M, Bacon SL, Lemière C, Malo JL, Lacoste G, Barone S, Verrier P, Ditto B: Are psychiatric disorders associated with worse asthma control and quality of life in asthma patients? Respir Med 2005, 99:1249-57.

53. Bacon S, Bouchard A, Loucks E, Lavoie KL: Individual-level socioeconomic status is associated with worse asthma morbidity in patients with asthma. Respir Res 2009, 10:125

54. McTaggart-Cowan HM, Marra CA, Yang Y, Brazier JE, Kopec JA, FitzGerald $J M$, Anis AH, Lynd LD: The validity of generic and condition-specific preference-based instruments: the ability to discriminate asthma control status. Qual Life Res 2008, 17:453-62.

55. Rowe B, Wong E, Blitz S, Diner B, Mackey D, Ross S, Senthilselvan A: Adding long-acting beta-agonists to inhaled corticosteroids after discharge from the emergency department for acute asthma: a randomized controlled trial. Acad Emerg Med 2007, 14:833-40.

56. Yacoub MR, Lavoie K, Lacoste G, Daigle S, L'Archevêque J, Ghezzo H, Lemière C, Malo JL: Assessment of impairment/disability due to occupational asthma through a multidimensional approach. Eur Respir $J$ 2007, 29:889-96.

57. Lavoie K, Bacon S, Barone S, Cartier A, Ditto B, Labrecque M: What is worse for asthma control and quality of life: depressive disorders, anxiety disorders, or both? Chest 2006, 130:1039-47.

58. Lavoie K, Bacon S, Labrecque M, Cartier A, Ditto B: Higher BMI is associated with worse asthma control and quality of life but not asthma severity. Respir Med 2006, 100:648-57.

59. Mo F, Choi B, Li F, Merrick J: Using Health Utility Index (HUI) for measuring the impact on health-related quality of life (HRQL) among individuals with chronic diseases. Sci World J 2004, 4:746-57.

60. Fitzgerald JM, Shragge D, Haddon J, Jennings B, Lee J, Bai T, Pare P, Kassen D, Grunfeld A: A randomized, controlled trial of high dose, inhaled budesonide vs. oral prednisone in patients discharged from the emergency department following an acute asthma exacerbation. Can Respir J 2000, 7:61-7.

61. Williams AE, Agier L, Wiklund I, Frith L, Gul N, Juniper E: Transcultural and measurement evaluation of the asthma quality-of-life questionnaire. Health Outcomes Research in Medicine 2010, 1:e69-e79.

62. Lavoie K, Bouthillier D, Bacon S, Lemière C, Martin J, Hamid Q, Ludwig M, Olivenstein R, Ernst P: Psychologic distress and maladaptive coping styles in patients with severe vs moderate asthma. Chest 2010, 137:1324-31.

63. Miedinger D, Lavoie K, L'Archevêque J, Ghezzo H, Zunzunuegui MV, Malo JL: Quality-of-life, psychological, and cost outcomes 2 years after diagnosis of occupational asthma. J Occup Environmental Med 2011, 53:231-8.

\section{doi:10.1186/1471-2466-13-70}

Cite this article as: Ismaila et al.: Clinical, economic, and humanistic burden of asthma in Canada: a systematic review. BMC Pulmonary Medicine 2013 13:70.

\section{Submit your next manuscript to BioMed Central and take full advantage of:}

- Convenient online submission

- Thorough peer review

- No space constraints or color figure charges

- Immediate publication on acceptance

- Inclusion in PubMed, CAS, Scopus and Google Scholar

- Research which is freely available for redistribution 